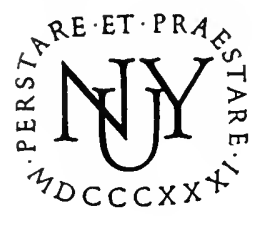

NEW YORK UNIVERSITY

Institute of Mathematical Sciences

Division of Electromagnefic Research

RESEARCH REPORT NO. EM-147

\title{
Decay Exponents and Diffraction Coefficients for Surface Waves on Surfaces of Non-Constant Curvature
}

JOSEPH B. KELLER and BERTRAM R. LEVY

Contract No. AF $19(604) 5238$

OCTOBER 1959 
. 
AFCRC-TN-59-353

NEW YORK UNIVERSITY

Institute of Mathematical Sciences

Division of Electromagnetic Research

Research Report No. EM-147

DECAY EXPONENTS AND DIFFRACIION COFFFICIENTS FOR SURFACE WAVES ON SURFACES OF NON-CONSTANT

CURVATURE

by

Joseph B. Keller

and

Bertram R. Levy

Josefzh B. Keller

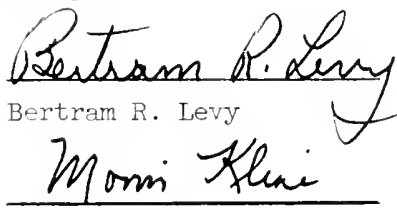

Morris Kline

Project Director

he. Whan

Contract Monitor

The research reported in this document has been sponsored by the Air Force Cambridge Research Center, Air Research and Development Command, under Contract No. AF 19(604)5238. 
Requests for additional copies by Agencies of the Department of Defense, their contractors, and other Government agencies should be directed to the:

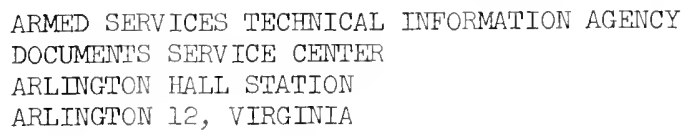

Department of Defense contractors must be established for ASTIA service or have their 'need-to-know' certifled by the cognizant military agency of their project or contract.

All other persons and organizations should apply to the:

U.S. DEPARTMENT OF COMMERCE OFFICE OF TECHNICAL SERV ICES

WASHINGTON 25, D.C. 
The diffraction of a plane scalar wave by a hard elliptic cylinder is investigated theoretically. The field is obtained and expanded asymptotically for incident wavelengths small compared with the dimensions of the generating ellipse. The method of obtaining the asymptotic expansion of the diffracted field parallels the methods of reference [9]. However, additional terms in the asymptotic expansion are obtained. In reference [9] it was shown that the asymptotic expansion of the diffracted field was in agreement with the geometrical theory of diffraction as presented in references [4] and [5]. The additional terms in the field obtained in this paper we interpret geometrically as higker order corrections to the decay exponents and diffraction coefficients as given in reference [5]. Finally, we obtain additional terms to those given in reference [8] for the asymptotic expansion of the field diffracted by a parabolic cylinder. We then show that these higher order corrections have the same geometrical interpretation as in the case of the elliptic cylinder. The determination of these corrections permits the geometric theory to be extended to longer wavelengths than could be treated previously. Similar results are obtained for soft cylinders. Then the field on a hard convex cylinder of arbitrary shape is determined asymptotically by a quite different method - that of asymptotically solving an integral equation. The result is found to coincide with the generalization based upon the solution for the elliptic cylinder.

\section{Table of Contents}

1. Introduction

2. Diffraction by an elliptic cylinder

3. Diffraction by a parabolic cylinder 3

4. Integral equation method

Appendix 

1. Introduction

When a wave is incident upon an opaque object large compared to the Incident wavelength a shadow is comed. Some radiation penetrates into the shadow. The first quantitative analysis of this penetration effect for the case of a smooth object was that of G. N. Watson [1]. He showed that the field in the shadow of a sphere consists of a sum of modes. Each mode decays exponentially with increasing distance from the shadow boundary into the shadow. Numerous authors have pursued Watson's analysis, constdering spheres which are not opaque or which are surrounded by non-uniform media. Many of these investigaton are described by H. Bremmer [2]. Independently W. Franz and K. Depperman [3] discovered the existence of an exponentially decaying wave travelling around a circular cylinder. They also observed that this wave continues travelling into the illuminated region. These results, as well as those referred to above pertain to bodles of constant curvature. What are the corresponding results for objects of non-constant curvature?

This question is answered by the geometrical theory of diffration introduced by J.B. Keller [4], which predicted that radiation travels along surface rays. These rays are geodesics on the surface of any object which originate at the shadow boundary. They continually shed diffracted rays which irradiate the shadow and also enter the 1 lluminated region. A quantitative theory of the fleld diffracted by a cylinder of arbitrary convex cross-section was constructed with the ald of these rays [5]. In this theory certain decay exponents and diffraction coefficlents were introduced. The decay exponents determine the rate of decay of the various field modes along a surface ray. The diffraction coefficients determine the amplitudes of the various modes on a surface ray, 
and the amplitude of the field on the shed diffracted rays. It was assumed that the decay exponents and diffraction coefficlents depend only upon local properties of the ray and the surface. By comparing the predictions of this theory with the results of $W$. Franz [6] for the circular cylinder, the decay exponents and diffraction coefficients were determined. A similar analysis was performed for three dimensional curved objects by B. R. Levy and J. B. Keller [7].

The results of the geometrical theory of diffraction have been tested by comparing them with the exact solutions of certain diffraction problems involving objects of non-constant curvature. To make this comparison it was necessary to expand the exact solution asymptotically for wavelength small compared to the dimensions of the object. This has been done for the field diffracted by a parabolic cylinder by S. O. Rice[8], an elliptic cylinder by B. R. Levy $[9]$ and by R. K. Ritt and N. D. Kazarinoff [10], and for an ellipsoid of revolution by J. B. Keller and B. R. Levy [II] and by R. K. Ritt and $N$. D. Kazarinoff $[12]$. In all cases the leading term in the asymptotic expansion agreed precisely with the results of the geometrical theory.

We now propose to improve the geometrical theory of diffraction by an arbitrary cylinder so that it will also yield the next term in the asymptotic expansion. To this end we must determine the next terms in the expressions for the decay exponents and the diffraction coefficients. The previously determined terms involve the radius of curvature of the cylinder. The new terms will involve the derivative of the radius with respect to arclength along the crosssectional curve. To find the new terms we shall examine the next term in the asymptotic expansion of the exact expression for the field diffracted by an elliptic cylinder. We shall express terms of local geometrical quantities such as the radius of curvature and its derivative. Then we shall assume that 
the final geometrical expression is correct for an arbitrary cylinder. As a first test of this result, we shall show that it correctly yields the next term for the field diffracted by a parabolic cylinder. Of course, it also yields the correct term in the case of a circular cylinder. The results are also obtained by asymptotically solving the integral equation for the cylinder current. These results coincide with those obtained by generalizing the results obtained for the elliptic cylinder.

The determination of these new corrections permits us to use our theory for longer wavelengths than could have been treated previously. The improvement resulting from the correction to the decay exponent is shown in [7].

\section{Diffraction by an elliptic cylinder}

Let us consider the field $u$ produced by a line source parallel to the generators of an elilptic cylinder. Then $u$ is the solution of the following problem

$$
\begin{aligned}
& \left(\Delta+k^{2}\right) u=\delta\left(\xi-\xi_{0}\right) \delta(\eta) \\
& \frac{\partial(a, \eta)}{\partial \xi}=0 \\
& \underset{r \rightarrow m}{\lim } r\left(i k u-u_{r}\right)=0 .
\end{aligned}
$$

For simplicity the source has been taken to lie in the plane containing the major axis of the ellipse. The elliptic coordinates $(\xi, \eta)$ are related to cartesian coordinates by the equations

$$
\begin{aligned}
& \mathrm{x}=\mathrm{h} \cosh \xi \cos \eta \\
& \mathrm{y}=\mathrm{h} \sinh \xi \sin \eta
\end{aligned}
$$


In (4) and (5) $\mathrm{h}$ denotes one half the interfocal distance of the ellipses $\xi=$ constant, of which $\xi=a$ is the cross-section of the cylinder.

In reference [9] it is shown that on the cylinder the solution of (1) - (3) can be written in the form

$$
u(a, \eta)=(k h)^{2} \sum_{n=1}^{\infty} b_{n} \frac{c_{n}(\eta-\pi)}{c_{n}^{\prime}(\pi)} \frac{v_{n}{ }^{(I)}\left(\xi_{0}\right)}{\partial / \partial b_{n} v^{(I)^{\prime}(a)}}
$$

The functions $C_{n}$ and $V_{n}(I)$ are defined and asymptotically expanded for large $k$ in reference [9]. A breif review of the pertinent properties of these functions follows.

The function $\mathrm{V}_{\mathrm{n}}(I)$ is the outgoing solution of the equation

$$
\frac{d^{2} v_{n}(I)}{d \xi^{2}}-(k h)^{2}\left(b_{n}^{2}-\cosh ^{2} \xi\right) v_{n}(I)=0 .
$$

For large kh it has the asymptotic expansion

$$
\mathrm{V}_{\mathrm{n}}{ }^{(1)}(\xi) \sim \xi^{1 / 4} 3^{1 / 3} \pi^{-1}\left(\mathrm{~b}_{\mathrm{n}}^{2}-\cosh ^{2} \xi\right)^{-1 / 4} \mathrm{~A}\left(3^{1 / 3} \mathrm{e}^{-1 \pi / 3}(\mathrm{kh})^{2 / 3} \xi\right)
$$

Here $b_{n}$ is defined by

$$
v_{n}(1)^{\prime}(a)=0 .
$$

The functions $\zeta$ and $A$ are defined by

$$
\frac{2}{3} \zeta^{3 / 2}=-\int_{\cosh ^{-1} b_{n}}^{\xi}\left(b_{n}^{2}-\cosh ^{2} x\right)^{1 / 2} d x
$$




$$
A(t)=\int_{0}^{\infty} \cos \left(z^{3}-t z\right) d z
$$

The function $C_{n}(\eta)$ is the even solution of the equation

$$
\mathrm{C}_{n}^{\prime \prime}+(k h)^{2}\left(b_{n}^{2}-\cos ^{2} \eta\right) c_{n}=0
$$

For large $\mathrm{kh}$ it has the asymptotic expansion

$$
c_{n} \sim \cos \left[k h \int_{0}^{7}\left(b_{n}^{2}-\cos ^{2} \eta\right)^{1 / 2} d \eta\right]\left\{\left(b_{n}^{2}-1\right) /\left(b_{n}^{2}-\cos ^{2} \eta\right)\right\}^{1 / 4} \cdot(13)
$$

We now specialize (6) to the case of plane wave incldence. To do this we multiply (6) by $\mathrm{e}^{3 \pi i / 4} 2^{3 / 2} \pi^{1 / 2}\left(\mathrm{kh} \cosh \xi_{0}\right)^{1 / 2} \exp \left[-i k h \cosh \xi_{0}\right]$ and let $\xi_{0} \rightarrow \infty$. Then we obtain

$$
u(a, \eta)=E \sum_{n=1}^{\infty} \frac{b_{n} c_{n}(\eta-\pi)}{c_{n}^{\prime}(\pi)} \frac{\exp \left[-1 k h \int_{0}^{\pi / 2}\left(b_{n}^{2}-\cos ^{2} \eta\right)^{1 / 2} d \eta\right]}{\partial / \partial b v_{n}^{(1)^{\prime}(a)}} .
$$

Here $E=e^{5 \pi i / 6} 2^{1 / 2}(k h)^{7 / 3}$. Upon expanding the $C_{n}$ function we find that (14) becomes

$$
\begin{aligned}
u(a, \eta) \sim & \frac{1 E}{k h} \sum_{n=1}^{\infty} b_{n}\left\{\left(b_{n}^{2}-1\right)\left(b_{n}^{2}-\cos ^{2} \eta\right)\right\}^{-1 / 4} \\
& \times \frac{\exp [i k h G(\pi / 2, \eta)]+\exp [i k h G(\eta, 3 \pi / 2)]}{\partial / \partial b V_{n}^{(1)^{\prime}}(a)}\{1-\exp [2 i k h G(0, \pi)]\}^{-1}
\end{aligned}
$$

The details of the evaluation of the limit are to be found in reference [n], p. 14 . 
In (15) $G$ is defined by

$$
G(\alpha, \beta)=\int_{\alpha}^{\beta}\left(b_{n}^{2}-\cos ^{2} n\right)^{1 / 2} d \eta
$$

In reference [9] the leading term in the asymptotic expansion of each of the summands in (15) was computed. In order to carry out this calculation it was found necessary to compute two terms in the asymptotic expansion of the eigenvalue $b_{n}$. We shall now compute a further term in the asymptotic expansion of each of the terms in (15). In order to do this we shall first compute another term in the asymptotic expansion of $b_{n}$. To do this we first observe that the leading terms in the asymptotic expansion of $V_{n}^{(I) '}(\xi)$ are obtained by differentiating (8). The leading term in the asymptotic expansion of $V_{n}^{(1)}(\xi)$ comes from differentiating the Airy function A. Therefore $\zeta_{n}$ will be nearly equal to the result obtained in [9] so we write it in the form

$$
\zeta_{n}=3^{-1 / 3} e^{i \pi / 3}(\mathrm{kh})^{-2 / 3}\left(1+\delta_{n}\right) q_{n} .
$$

Here $\zeta_{n}=\zeta(a), q_{n}$ is the nth root of the equation $A^{\prime}\left(q_{n}\right)=0$, and $\delta_{n}$ is an as yet undetermined correction which is small compared to unity. We now set $b_{n}=\cosh a+\epsilon_{n}$ and insert this expression into (10) which determines $\zeta$. In this way we obtain

$$
\frac{2}{3} \zeta_{n}^{3 / 2}=\frac{2^{3 / 2}}{3} \frac{(\cosh a)^{1 / 2}}{\sinh a} \epsilon_{n}^{3 / 2}-\frac{2^{1 / 2} \epsilon_{n}^{5 / 2}\left(\cosh ^{2} a+7\right)}{30 \sinh ^{3} a(\cosh a)^{1 / 2}}+o\left(\epsilon_{n}^{7 / 2}\right) \cdot
$$


Now we insert (17) and the above form of $b_{n}$ into (9) and obtain the following result for $\delta_{n}$

$$
\delta_{n}=\frac{3^{2 / 3} e^{1 \pi / 3}\left(\cosh ^{2} a+15 \sinh ^{2} a+7\right)}{802^{1 / 3}(\sinh a \cosh a)^{4 / 3}(k h)^{2 / 3}}+o\left((k h)^{-4 / 3}\right) .
$$

By comparing (18) and (17), and using (19) for $\delta_{n}$. we determine $\epsilon_{n}$. Then $\mathrm{b}_{\mathrm{n}}$ is given by

$$
\begin{aligned}
b_{n}= & \cosh a+\frac{\tau_{n}(\sinh a)^{2 / 3}}{(\cosh a)^{1 / 3}(k h)^{2 / 3}}+\frac{\tau_{n}^{2}\left(\cosh ^{2} a+7\right)}{30(\sinh a)^{2 / 3}(\cosh a)^{5 / 3}(k h)^{4 / 3}} \\
& -\frac{\left(2 \cosh ^{2} a-1\right)}{20 \tau_{n}(\sinh a)^{2 / 3}(\cosh a)^{5 / 3}(k h)^{4 / 3}}+o\left((k h)^{-2}\right) .
\end{aligned}
$$

In (20), the quantity $\tau_{n}$ is defined in terms of $q_{n}$ by

$$
\tau_{n}=\frac{q_{n} e^{i \pi / 3}}{6^{1 / 3}}
$$

Upon substituting (20) into (16) and asymptotically expanding the the integral, we obtain

$$
\begin{aligned}
\operatorname{ikhG}(\alpha, \beta)= & i k h \int_{\alpha}^{\beta}\left(\cosh ^{2} a-\cos ^{2} \eta\right)^{1 / 2} d \eta+1(k h)^{1 / 3}(\sinh a \cosh a)^{2 / 3}(22) \\
& \times \int_{\alpha}^{\beta}\left(\cosh ^{2} a-\cosh ^{2} \eta\right)^{-1 / 2} a \eta+\frac{i \tau_{n}^{2}}{30(k h)^{1 / 3}(\cosh a \sinh a)^{2 / 3}}
\end{aligned}
$$




$$
\begin{aligned}
& \times \int_{a}^{\beta}\left(\cosh ^{2} a-\cos ^{2} \eta\right)^{-3 / 2}\left\{\left(\cosh ^{2} a+7\right)\left(\cosh ^{2} a-\cos ^{2} \eta\right)\right. \\
& \left.-15 \sinh ^{2} a \cos ^{2} \eta\right\} a \eta-\frac{1\left(2 \cosh ^{2} a-1\right)}{20 \tau_{n}(k h)^{1 / 3}(\sinh a \cosh a)^{2 / 3}} \\
& \times \int_{a}^{\beta}\left(\cosh ^{2} a-\cosh ^{2} \eta\right)^{-1 / 2} a \eta+o\left((k h)^{-1}\right) .
\end{aligned}
$$

In reference [9] it was shown that the first two integrals in (22) have simple geometric interpretations in terms of the arclength $\mathrm{s}$ along the ellipse. To show this we let $s_{1}$ and $s_{2}$ be the values of $s$ corresponding to $\eta=a$ and $\eta=\beta$ respectively. Then we find that the first term on the right of (22) is just ik times the arclength

$$
1 k \int_{s_{1}}^{s} d s .
$$

Similarly, the second term on the right of (22) is

$$
1 k^{1 / 3} \tau_{n} \int_{s_{1}}^{s_{2}} b^{-2 / 3} d s
$$

Here $b(s)$ denotes the radius of curvature of the ellipse.

We shall now express the third and fourth terms appearing on the right side of (22) in geometric terms. 
The third term can be written as

$$
\frac{1 \tau_{n}^{2}}{30 k^{1 / 3}} \int_{s_{1}}^{s} b^{-4 / 3}\left(1+\frac{16}{9} b_{s}^{2}-\frac{8 b b s s}{3}\right) d s .
$$

The fourth term is equal to

$$
-\frac{i}{20 \tau_{n} k^{1 / 3}} \int_{s_{1}}^{s} b^{-4 / 3}\left(2+\frac{2}{9} b_{s}^{2}-\frac{b b s s}{3}\right) d s .
$$

The second derivatives in (25) and (26) can be eliminated by integrating by parts. Then (25) and (26), respectively become

$$
\begin{aligned}
& \frac{1 \mathrm{n}^{2}}{30 \mathrm{k}^{1 / 3}}\left\{-\frac{8}{3} \frac{\mathrm{b}_{\mathrm{s}}}{\mathrm{b}^{1 / 3}}\right]_{\mathrm{s}_{1}}^{\mathrm{s}_{2}}+\int_{\mathrm{s}_{1}}^{\mathrm{s}_{2}} \mathrm{~b}^{-4 / 3}\left(1+\frac{8}{9} \mathrm{~b}_{\mathrm{s}}^{2}\right) \mathrm{ds} . \\
& -\frac{1}{20 \mathrm{r}^{1 / 3}}\left\{-\frac{1}{3} \frac{\mathrm{b}_{\mathrm{s}}}{\mathrm{b}^{1 / 3}}\right]_{\mathrm{s}_{1}}^{\mathrm{s}_{2}}+\int_{\mathrm{s}_{1}}^{\mathrm{s}^{2}} \mathrm{~b}^{-4 / 3}\left(2+\frac{1}{9} \mathrm{~b}_{\mathrm{s}}{ }^{2}\right) \mathrm{ds} .
\end{aligned}
$$

Let us now insert (22) into the expression (15) for $u(a, \eta)$. In doing so we shall utilize the geometric forms (23), (24), (27) and (28) for the integrals in (22). We must also evaluate $\partial v_{n}^{\prime}(a) / \partial b$ which we find, by the methods of reference [9], to be given by 


$$
\begin{aligned}
\frac{\partial}{\partial b} V_{n}^{\prime}(a) \sim \pi^{-1}(k h)^{4 / 3} 2^{1 / 2}(\sinh a)^{-1 / 2}(\cosh a)^{1 / 2} e^{-2 i \pi / 3} \\
\quad<q_{n} A\left(q_{n}\right)+0\left((k h)^{2}\right) .
\end{aligned}
$$

When all these expressions are inserted into (15), we finally obtain the following asymptotic formula for $u$ :

$$
\begin{aligned}
u(a, \eta)= & \frac{\pi(\cosh a)^{1 / 2}}{\left(\cosh ^{2} a-\cos ^{2} \eta\right)^{I / 4}} \sum_{n=0}^{\infty}\left\{q_{n} A\left(q_{n}\right)\right\}^{-1}\left\{\exp \left[i k t_{1}+\int_{Q_{1}}^{P} \beta_{n} d s\right]\right. \\
& \left.+\exp \left[i k t_{2}+\int_{Q_{2}}^{P} \beta_{n} d s\right]\right)\left\{\gamma_{n}+o(k h)^{-2 / 3}\right\} \\
& \times\left\{\begin{array}{l}
1+\exp \left[i k T-\beta_{n} d s\right] \\
0
\end{array}\right\}
\end{aligned}
$$

In (30) the distances $t_{1}$ and $t_{2}$ and the points $Q_{1}, Q_{2}$ and $P$ are as shown in figure 1 . The distance $T$ is the total arclength of the ellipse.

The quantities $\beta_{\mathrm{n}}$ and $\gamma_{\mathrm{n}}$ are defined by

$$
\begin{aligned}
& \beta_{n}=i \tau_{n} k^{1 / 3} b^{-2 / 3}+\frac{1 \tau_{n}^{2}}{30 k^{1 / 3}} b^{-4 / 3}\left(1+\frac{8}{9} b b_{s}^{2}\right) \\
& -\frac{1}{20 \tau_{n} k^{1 / 3}} b^{-4 / 3}\left(2+\frac{1}{9} b_{s}^{2}\right) \text {. }
\end{aligned}
$$




$$
\gamma_{n}=\exp \left[\frac{e^{i \pi / 6} \sigma^{1 / 3} b s(p)}{k^{1 / 3} b^{1 / 3}(P)} \quad\left(\frac{q_{n}^{2}}{45}+\frac{1}{60 q_{n}}\right)\right] .
$$

We shall now relate (30) to the geometric theory of diffraction presented in reference [5]. When this theory is applied to the present case it yields

$$
\begin{aligned}
u^{d}(P)= & 2^{1 / 2} \sigma^{1 / 3} \pi^{-1 / 2} k^{I / 6} e^{-1 \pi / 1 \partial_{b}-1 / 3}(P) \sum_{n=0}^{\infty} A\left(q_{n}\right) B_{n}(P) \\
& \left\{B_{n}\left(Q_{1}\right) \exp \left[i k t_{1}+\int_{Q_{1}}^{P} \beta_{n} d s\right]+B_{n}\left(Q_{2}\right) \exp \left[i k t_{2}+\int_{Q_{2}}^{P} \beta_{n} d s\right]\right\} \\
& \left\{1-\exp \left[i k T-\int_{0}^{T} \beta_{n} d s\right]\right\}^{-1}
\end{aligned}
$$

Here $\beta_{n}$ and $B_{n}$ are respectively the decay exponent and diffraction coefficient of the nth mode. The leading terms $\beta_{n}{ }^{\circ}$ and $\mathrm{B}_{n}{ }^{\circ}$ in the expressions for these quantities, as given in reference [5], are

$$
\begin{gathered}
\beta_{n}{ }^{\circ}=i \tau_{n} k^{I / 3} b^{-2 / 3} \\
B_{n}{ }^{O}(P)=\pi^{3 / 4} 2^{-1 / 4} 6^{-1 / 6} k^{-1 / 2}\left[q_{n}^{1 / 2} A\left(q_{n}\right)\right]^{-1} e^{1 \pi / 24} b^{1 / 6}(P) .
\end{gathered}
$$

Upon comparing (33) and (30) we see that they are identical provided that the decay exponent $\beta_{n}$ is given by (31) and the diffraction $B_{n}(P)$ by 


$$
B_{n}(P)=B_{n}^{0}(P) \gamma_{n}(P)
$$

The new results (31) and (36) for $\beta_{n}$ and $B_{n}$ agree with the previous results (34) and (35) to the lowest order in $k^{-1}$. The new value of $\beta_{n}$ is valid to $O\left(k^{-2 / 3}\right)$ and the new value of $B_{n}$ to $O\left(k^{-3 / 4}\right)$. Thus they contain corrections to the previous results.

The preceding results pertain to a hard elliptic cylinder - i.e one on which $\partial \mathrm{u} / \partial \mathrm{n}=0$. We have performed a similar calculation for a soft elliptic cylinder - i.e, one on which $u=0$. In this case we also find corrections to the decay exponents and to the diffraction coefficients. For the decay exponents we obtain

$$
\beta_{n}=i \tau n^{1 / 3} b^{-2 / 3}+\frac{i \tau n^{2} b^{-4 / 3}}{30 k^{1 / 3}}\left(1+\frac{8}{9} b_{s}^{2}\right) \text {. }
$$

Here $\tau_{n}=6^{-1 / 3} q_{n} e^{i \pi / 3}$ and $q_{n}$ is the nth root of the equation $A\left(q_{n}\right)=0$. For the diffraction coefficients we find

$$
B_{n}(P)=B_{n}^{0}(P) \exp \left[\frac{e^{i \pi / 6} \sigma^{1 / 3} b_{s}(P) q_{n}^{2}}{45 k^{1 / 3} b^{1 / 3}(P)}\right] .
$$

Here $B_{n}{ }^{\circ}(P)$ is the lowest order result for the diffraction coefficient, given in reference [5], as

$$
\mathrm{B}_{\mathrm{n}}{ }^{\circ}(\mathrm{P})=\pi^{3 / 4} 2^{1 / 4} 6^{-2 / 3} \mathrm{k}^{-1 / 12}\left[\mathrm{~A}^{\prime}\left(\mathrm{q}_{\mathrm{n}}\right)\right]^{-1} \mathrm{e}^{i \pi / 24} \mathrm{~b}^{1 / 6}
$$


The new results (37) and (39) contain corrections to the previous results, as in the hard case.

We now assume that the results (31) and (36) apply to any hard cylinder and that (37) and (38) apply to any soft cylinder. Of course the cylinder must have a smooth cross section. As a first check on these results we see that when $b_{s}=O(31)$ and (37) agree with the results $(A l 7 a)$ and $(A l 7 b)$ of $W$. Franz $[6]$ for a circular cylinder.

\section{Diffraction by a parabolic cylinder.}

As a check on the higher order corrections to the decay exponents and diffraction coefficients which were derived in Section 2 we now consider the problem of diffraction by a parabolic cylinder. Our solution will closely parallel that of S. O. Rice [8]. However, we find it more convenient to use parabolic cylinder functions which differ from his and hence we wili rederive his results. We again consider the problem of evaluating the field on the surface of a hard parabolic cylinder due to an incident plane wave. For convenience we first consider the diffraction problem for an incident cylindrical wave and then obtain the plane wave result by a limiting procedure.

To formulate the diffraction problem we take the $z$ axis of an $(x, y, z)$ rectangular coordinate axis to be parallel to the generators of the parabolic cylinder. In the $(x, y)$ plane we introduce parabolic coordinates $(\xi, \eta)$ through

$$
\begin{aligned}
& \mathrm{x}=\xi \eta \\
& \mathrm{y}=\frac{1}{2}\left(\eta^{2}-\xi^{2}\right) .
\end{aligned}
$$


Here $\eta>0$ and $-\infty<\xi<\infty$. The parabolic cylinder is defined by $\eta=$ constant $=\eta_{0}$. The line source is located at $y=0, x=x_{0}$, i.e. $\xi=\eta=a=x_{0}^{1 / 2}$. The wave function $u(\xi, \eta)$ then satisfies the equation

$$
u_{\xi \xi}+u_{\eta \eta}+k^{2}\left(\xi^{2}+\eta^{2}\right) u=\delta(\xi-a) \delta(\eta-a) .
$$

In addition $u$ satisfies the boundary condition

$$
u_{\eta}(a, \xi)=0
$$

and the Sommerfeld radiation condition

$$
\lim _{r \rightarrow \infty} r\left(i k u-u_{r}\right)=0 .
$$

Now to find $u$ we first note that the product $\phi(\xi) \psi(\eta)$ satisfies (2) with the delta functions replaced by zero if $\phi$ and $\psi$ satisfy the ordinary differential equations

$$
\begin{aligned}
& \psi^{\prime \prime}-k^{2}\left(b^{2}-\eta^{2}\right) \psi=0 \\
& \phi^{\prime \prime}+k^{2}\left(b^{2}+\xi^{2}\right) \phi=0 .
\end{aligned}
$$

Here $b$ is an arbitrary separation constant. We next note that for an infinite set $b_{n}$ of values of $b$, there exist solutions of $(5), \psi_{n}(\eta)$, which are 'outgoing ', and for which

t Since the polar coordinate variable $r$ is equal to $\xi^{2}+n_{1}^{2} / 2$ we take the outgoing condition on $\psi$ to mean that as $\eta \rightarrow \infty, \psi \rightarrow A e^{i k \eta^{2} / 2}$. Here and in the following $A$ will denote a generic amplitude function. 


$$
\Psi_{n}{ }^{\prime}(a)=0 .
$$

We next assume that the $\Psi_{n}(\eta)$ are complete and express $u$ as

$$
u(\xi, \eta)=\sum_{n=0}^{\infty} \Phi_{n}(\xi) \psi_{n}(\eta)
$$

By exactly the same calculation as was carried out in reference [9] It is easy to show that

$$
\int_{n_{0}}^{\infty} \psi_{n}\left(\eta_{1}\right) \psi_{m}\left(\eta_{0}\right)=-\delta_{n m}\left(2 k^{2} b_{n}\right)^{-1} \psi_{n}\left(\eta_{0}\right) \frac{\partial}{\partial b} \psi_{n}^{1}\left(\eta_{0}\right) .
$$

Here $\delta_{n m}$ is the Kronecker delta and $\partial / \partial b \psi_{n}{ }^{\prime}\left(\eta_{0}\right)$ is the value of $\partial / \partial b \psi^{\prime}(\eta)$ evaluated at $\mathrm{b}=\mathrm{b}_{\mathrm{n}}$ and $\eta=\eta_{0}$. Thus upon substituting (7) into (2) mult1plying by $\psi_{n}(\eta)$, integrating from $\eta_{0}$ to $\infty$, and making use of (8) we find that $\Phi_{n}$ satisfies

$$
\Phi_{n}^{\prime \prime}+k^{2}\left(b^{2}+\xi^{2}\right) \Phi_{n}=\frac{-2 k^{2} b_{n} \psi_{n}(a)}{\psi_{n}\left(\eta_{0}\right) \partial / \partial b \psi_{n}^{\prime}\left(\eta_{0}\right)} \delta(\xi-a)
$$

To solve (9) we first characterize the solutions of (6) by means of their asymptotic expansions as $k \rightarrow \infty$. As $k \rightarrow \infty$ there exist solutions $\phi^{(I)}(\xi)$ and $\phi^{(2)}(\xi)$ having the following asymptotic expansions

$$
\phi^{(I)}(\xi) \sim\left(b^{2}+\xi^{2}\right)^{-1 / 4} \exp \left[i k \int_{0}^{\xi}\left(b^{2}+\xi^{2}\right)^{1 / 2} d \xi\right]
$$




$$
\phi^{(2)}(\xi) \sim\left(b^{2}+\xi^{2}\right)^{-1 / 4} \exp \left[-i k \int_{0}^{\xi}\left(b^{2}+\xi^{2}\right)^{1 / 2} d \xi\right] .
$$

A simple calculation shows that as $|\xi| \rightarrow \infty$

$$
\begin{aligned}
& \phi^{(1)} \sim A \exp [i k \xi|\xi| / 2] \\
& \phi^{(2)} \sim A \exp [-i k \xi|\xi| / 2] .
\end{aligned}
$$

It is thus apparent that as $\xi \rightarrow \infty, \phi^{(1)}$ is the outgoing solution of (6), while as $\xi \rightarrow-\infty, \phi^{(2)}$ is the outgoing solution of (6). Since the variable $\xi$ takes on both positive and negative values, we see that for $\xi>\xi$ o the solution of (9) is proportional to $\phi^{(1)}(\xi)$, while for $\xi<\xi$ the solution of (9) is proportional to $\phi^{(2)}(\xi)$. These conditions together with the jump conditions imposed by the delta function allow a unique determination of $\Phi_{n}(\xi)$. We then find that for $\xi<\xi$ o

$$
u(\xi, \eta)=i k \sum_{n=0}^{\infty} b_{n} \psi_{n}(\eta) \phi_{n}^{(2)}(\xi) \frac{\phi_{n}^{(1)}(a) \psi_{n}(a)}{\psi_{n}\left(\eta_{0}\right) \partial / \partial b \psi_{n}^{\prime}\left(\eta_{0}\right)} .
$$

Now to pass to plane wave excitation we multiply by 


$$
c=e^{3 \pi i / 4} 2^{3 / 2} \pi^{1 / 2} k^{1 / 2} a e^{-i k a^{2}}
$$

and let $a \rightarrow \infty$. In order to evaluate this limit we require the asymptotic expans on of the function $\psi_{n}(a)$. Using the methods of olver [13] as in Section II we find

$$
\psi_{n}(\eta) \sim \xi^{1 / 4} 3^{1 / 3} \pi^{-1}\left(b^{2}-\eta^{2}\right)^{-1 / 4} \mathrm{~A}\left(3^{1 / 3} \mathrm{e}^{-i \pi / 3} \mathrm{k}^{2 / 3} \zeta\right)
$$

Here

$$
\frac{2}{3} \zeta^{3 / 2}=\int_{b}^{\eta}\left(b^{2}-\eta^{2}\right)^{1 / 2} d \eta
$$

When $\eta>b$, (16) becomes

$$
\psi_{n}(\eta) \sim e^{i \pi / 12} k^{-1 / 6} 2^{-1} \pi^{-1 / 2}\left(\eta^{2}-b^{2}\right)^{-1 / 4} \exp \left[i k \int_{b}^{\eta}\left(\eta^{2}-b^{2}\right)^{I / 2} d \eta\right] .
$$

Now a simple calculation shows that as $n \rightarrow \infty$

$$
\int_{b}^{\eta}\left(\eta^{2}-b^{2}\right)^{1 / 2} d \eta \sim--\frac{b^{2}}{2} \log \frac{2 \eta}{b}+\frac{\eta^{2}}{2} .
$$

Also as $\xi \rightarrow \infty$

$$
\int_{0}^{\xi}\left(\xi^{2}+b^{2}\right)^{1 / 2} d \xi \sim \frac{b^{2}}{2} \log \frac{2 \xi}{b}+\frac{\xi^{2}}{2} .
$$




$$
\lim _{a \rightarrow \infty} c \phi_{n}^{(I)}(a) \psi_{n}(a)=2^{I / 2} k^{I / 3} e^{5 \pi i / 6}
$$

Thus for $\eta=\eta_{0}$ and for an incident plane wave (14) becomes

$$
u\left(\xi, \eta_{0}\right)=k^{4 / 3} e^{4 \pi i / 3} 2^{1 / 2} \sum_{n=0}^{\infty} b_{n} \frac{\phi_{n}^{(2)}(\xi)}{\partial / \partial b \psi_{n}^{(1)}\left(\eta_{0}\right)} .
$$

To obtain the asymptotic expansion of (22) as $k \rightarrow \infty$ we proceed exactly as in the case of the elliptic cylinder. We first find the following three term asymptotic expansion of $b_{n}$ from the condition that $\psi_{n}^{\prime}\left(\eta_{0}\right)=0$.

$$
b_{n}=\eta_{0}+\frac{\tau_{n}}{k^{2 / 3} \eta_{0}^{1 / 3}}-\frac{7}{30} \frac{\tau_{n}^{2}}{k^{4 / 3} \eta_{0}^{5 / 3}}-\frac{1}{20 \tau_{n} k^{4 / 3} \eta_{0}^{5 / 3}}+o\left(k^{-2}\right) .
$$

Then upon using (23) in (16) and (11) we find

$$
\partial / \partial b \psi_{n}^{\prime}\left(\eta_{0}\right)=\pi^{-1} e^{-2 i \pi / 3} q_{n} A\left(q_{n}\right) 2^{1 / 2} \eta_{0}^{1 / 2} k^{4 / 3}+o\left(k^{2}\right)
$$

$$
\begin{aligned}
& \phi_{n}^{(2)}(\xi)=\left(\eta_{0}^{2}+\xi^{2}\right)^{-1 / 4} \exp \left[-1 k \int_{0}^{\xi}\left(\eta_{0}^{2}+\xi^{2}\right)^{1 / 2} d \xi-i k^{1 / 3} \tau n_{0}^{2 / 3}\right. \\
& \times \int_{0}^{\xi}\left(\eta_{0}^{2}+\xi^{2}\right)^{-1 / 2} d \xi-\frac{i \tau^{2} \eta_{0}^{4 / 3}}{30 k^{1 / 3}} \int_{0}^{\xi}\left(\eta_{0}+\xi^{2}\right)^{-3 / 2} \\
& \left.\times\left(8 \xi^{2} / \eta_{0}^{2}-7\right) d \xi+\frac{1}{20 \tau_{n} k^{1 / 3} \eta_{0}^{2 / 3}} \int_{0}^{\xi}\left(\eta_{0}^{2}+\xi^{2}\right)^{-1 / 2} d \xi\right]
\end{aligned}
$$


Upon substituting (24), (25) and (23) into (22) we find

$$
\begin{aligned}
& u\left(\xi, \pi_{0}\right)=\pi \eta_{0}^{1 / 2}\left(\pi_{0}^{2}+\xi^{2}\right)^{-1 / 4} \sum_{n=0}^{\infty}\left[q_{n} A\left(q_{n}\right)\right]^{-1}\left\{\operatorname { e x p } \left[-i k \int_{0}^{\xi}\left(\eta_{0}{ }^{2}+\xi^{2}\right)^{1 / 2} d \xi\right.\right. \\
& -1 k^{I / 3} \tau n_{0}^{2 / 3} \int_{0}^{\xi}\left(\eta_{0}^{2}+\xi^{2}\right)^{-I / 2} d \xi-\frac{i \tau_{n}^{2} \eta_{0}^{4 / 3}}{30 k^{I / 3}} \int_{0}^{\xi}\left(\eta_{0}{ }^{2}+\xi^{2}\right)^{-3 / 2} \\
& \left.\left.\times\left(8 \xi^{2} / \pi_{0}^{2}-7\right) d \xi+\frac{1}{20 \tau k^{1 / 3} \eta_{0}^{2 / 3}} \int_{0}^{\xi}\left(\eta_{0}^{2}+\xi^{2}\right)^{-1 / 2} d \xi\right]+0\left(k^{-2 / 3}\right)\right\} .
\end{aligned}
$$

In the case of the parabolic cylinder the incident rays are parallel to the $x$ axis and the diffracted ray to the point $\left(\xi, \eta_{0}\right)$ follows the path QP as shown in Figure 2.

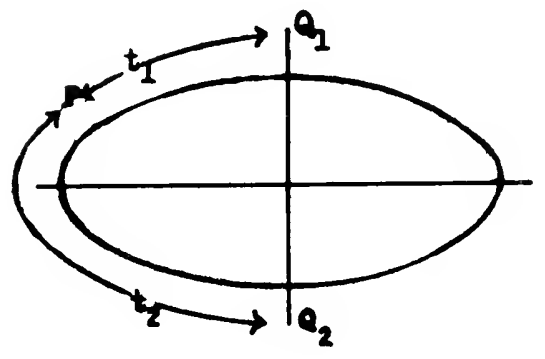

Figure 1

A cross section of the elliptic cylinder showing the points $Q_{1}$ and $Q_{2}$ at which two incident rays are tangent to it. The incident fleld is a plane wave coming from the right. The tangent rays produce diffracted rays which travel distances $t_{1}$ and $t_{2}$ to a point $P$ on the surface.

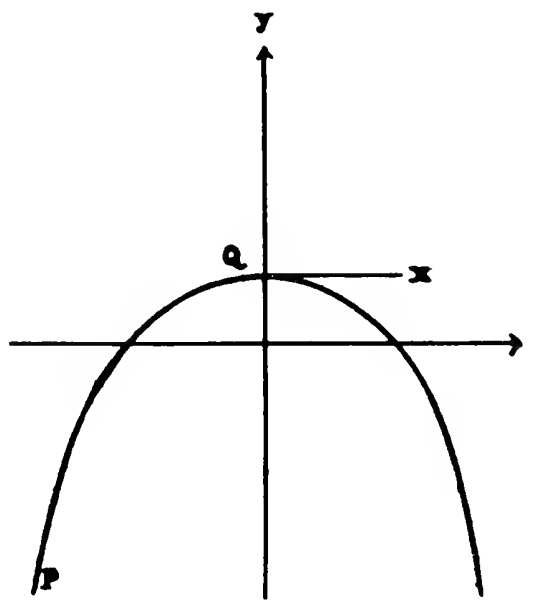

Figure 2

A cross section of the parabolic cylinder. The incident field is a plane wave coming from the right. The diffracted ray follows the parabolic path QP. 
A simple calculation shows that the element of arclength along the parabola, ds, is given by

$$
\mathrm{ds}=\left(\xi^{2}+\eta_{0}^{2}\right)^{1 / 2}|\mathrm{~d} \xi|
$$

Thus the first term in the exponent in (26) is ikt, since $\xi$ is negative. Similarly, we find that the radius of curvature of the parabola, b, is given by

$$
b=n_{0}^{-1}\left(\eta_{0}^{2}+\xi^{2}\right)^{3 / 2}
$$

Upon using (27) and (28) a simple calculation shows that the exponent in (26) can be written as

$$
\gamma_{n} \exp \left[i k t+\int_{Q}^{P} \beta_{n} d s\right] .
$$

Here $\beta_{\mathrm{n}}$ and $\gamma_{\mathrm{n}}$ are defined by (31) and (32) of Section II. Upon applying the geometric theory of reference [5] to the present case it is easy to show that the geometric construction agrees with (26) to lowest order in $\mathrm{k}^{-1}$. Again we have in (26) higher order corrections to the diffraction coefficients $B_{n}{ }^{\circ}(P)$ and the decay exponents $\beta_{n}{ }^{\circ}$ as given by equations (34) and (35) of Section II. These corrections are identical with those given by equations (3I) and $(36)$ of section II. 
4. Integral equation method.

We will now derive the asymptotic expansion of each mode of the diffracted field on an arbitrary convex cylinder by a different method. In this method we begin with an integral equation and obtain a formal asymptotic solution of it. This asymptotic solution coincides with the expression for a mode given by the geometric theory of diffraction, with the corrected decay exponents and diffraction coefficients found in section 2. This independent derivation, which follows the procedure used by $W$. Franz and K. Depperman [3] in the case of a circular cylinder, confirms our previous result.

We consider the two dimensional problem of finding a function $u(x, y)$ satisfying the following equations

$$
\begin{gathered}
\left(\nabla^{2}+k^{2}\right) u=0 \quad \text { in } D \\
\text { cu/on }=0 \quad \text { on } \mathrm{C} \\
\lim _{r \rightarrow \infty} r^{1 / 2}\left(\frac{\partial u}{\partial r}-i k u\right)=0 .
\end{gathered}
$$

Here $\mathrm{C}$ is a given simple smooth convex curve with a piecewise continuous second derviative. If $\mathrm{C}$ is closed, $\mathrm{D}$ denotes its exterior. If $\mathrm{C}$ is open and extends to infinity, $D$ denotes the non-convex portion of the plane, bounded by $\mathrm{C}$.

From (1) - (3) it follows that on C, u satisfies the following integral equation

$$
u(s)=-\frac{i}{2} \int_{C} u\left(s^{\prime}\right) \frac{d}{\mathrm{cn}^{\dagger}} H_{0}^{(I)}\left[\operatorname{kr}\left(\mathrm{s}, \mathrm{s}^{\prime}\right)\right] \mathrm{d} \mathrm{s}^{\prime} .
$$


Here $s$ denotes arclength along $\mathrm{C}$ measured from some fixed point, $u(s)$ is the value of $u$ at the point $s$ on $c, r\left(s, s^{\prime}\right)$ is the distance between the points $s$ and $s^{\prime}$, and the normal $n^{\prime}$ points into $D$.

If $\mathrm{C}$ is closed, the only single-valued solution of (4) 's $u \equiv 0$. If $\mathrm{C}$ is open, presumably the only bounded solution is also $\mathrm{u} \equiv 0$. Therefore if $u$ is to represent a mode, it must be multi-valued in the former case, or unbounded in the latter case. Consequently we assume that on $\mathrm{C}$ a single mode $u$ has the following asymptotic expansion for large values of $k$

$$
u(s) \sim \exp \left[i k s+\sum_{n=-1}^{\infty} v_{n}(s) k^{-n / 3}\right]
$$

The coefficients $v_{n}(s)$ are to be determined by requiring (5) to satisfy (4) asymptotically.

Before inserting (5) into (4), we note that for large values of $\mathrm{k}$ the function $\partial \mathrm{H}_{\mathrm{O}}^{(1)}\left[\mathrm{k} r\left(\mathrm{~s}, \mathrm{~s}^{\prime}\right)\right] / \partial n^{\prime}$ has the asymptotic expansion

$$
\frac{\partial H_{0}^{(l)}\left[k r\left(s, s^{\prime}\right]\right.}{\partial n^{\prime}} \sim \frac{\partial r}{\partial n^{\prime}}\left(\frac{2 k}{\pi r}\right)^{1 / 2} e^{1(k r+\pi / 4)} \sum_{m=0}^{\infty} \frac{(-1)^{m}(0, m)}{(2 i k r)^{m}}\left[I-\frac{m+1 / 2}{i k r}\right] .
$$

The symbol $(0, m)$ is defined by

$$
(0, m)=\Gamma\left(\frac{1}{2}+m\right) / m ! \Gamma\left(\frac{1}{2}-m\right)
$$

Now we insert (5) and (6) into (4) and then divide by the left hand side of the resulting equation. In this way we obtain the equation 


$$
\begin{aligned}
I \sim e^{-i \pi / 4}(k / 2 \pi)^{1 / 2} & \int_{C} \frac{\partial r}{\partial n}, r^{-1 / 2} \sum_{m=0}^{\infty}(-1)^{m}(0, m)(2 i k r)^{-m}\left[1-\frac{m+1 / 2}{i k r}\right] \\
& \times \exp \left[i k ( r - s - s ^ { \prime } ] \operatorname { e x p } \left[\sum_{n=-1}^{\infty} k^{-n / 3}\left(v_{n}\left(s^{\prime}\right)-v_{n}(s)\right] d s^{\prime} .\right.\right.
\end{aligned}
$$

In order to determine the $v_{n}(s)$ from (8) we first expand the integral in (8) asymptotically for large values of $\mathrm{k}$. We perform this expansion by using the concept of stationary phase. The derivative of the phase of the integrand is $1+\mathrm{dr} / \mathrm{ds}{ }^{1}$, which vanishes if $\mathrm{dr} / \mathrm{d} \mathrm{s}^{\prime}=-1$. This condition is satisfied only at $\mathrm{s}^{\prime}=\mathrm{s}$, and then only if $\mathrm{ar} / \mathrm{ds}$ ' denotes the one sided derivative computed with $\mathbf{s}^{\prime}<s$. Thus to evaluate the integral we expand the integrand in the one sided neighborhood $s^{\prime}<s$ of the point $s^{\prime}=s$. For this purpose we use the following expansions which are derived in the appendix

$$
\begin{aligned}
& r=\sum_{n=1}^{\infty} c_{n}(s)\left(s-s^{\prime}\right)^{n} \\
& \left.r^{-1 / 2} \partial r / \partial n^{\prime}=-\frac{\varphi(s)}{2}\left(s^{\prime}-s^{\prime}\right)^{1 / 2} \sum_{n=0}^{\infty} \rho_{n} i s\right)\left(s^{\prime}-s^{\prime}\right)^{n} \\
& \sum_{m=0}^{\infty}(-1)^{m}(0, m)(21 k r)^{-m}\left[1-\frac{m+1 / 2}{i k r}\right]=\sum_{n=-\infty}^{\infty} \beta_{n}(s, k)\left(s^{\prime}-s^{\prime}\right)^{n}
\end{aligned}
$$

Here $(s)$ denotes the curvature of $c$. The first few of the coefficients $c_{n}, \rho_{n}$ and $\beta_{n}$ are listed in Table $I$. 
We now insert (9) - (11) into (8), making use of the explicit values of $\rho_{0}, c_{1}, c_{2}$ and $c_{3}$. We also expand $v_{-1}\left(s^{\prime}\right)$ in a power series about the point $s^{\prime}=s$. Then (8) assumes the form

$$
\begin{aligned}
& I \sim e^{3 \pi i / 4} \cdot(s)(k / 8 \pi)^{I / 2} \int_{-\infty}^{s}\left(s-s^{\prime}\right)^{I / 2} \exp \left[-\frac{i k k^{2}(s)}{24}\left(s-s^{\prime}\right)^{3}\right. \\
& \left.-\mathrm{k}^{1 / 3} \dot{\mathrm{v}}_{-1}(\mathrm{~s})\left(\mathrm{s}-\mathrm{s}^{\prime}\right)\right] \mathrm{F}\left(\mathrm{k}, \mathrm{s}, \mathrm{s}^{\prime}\right) \mathrm{d} \mathrm{s}^{\prime} .
\end{aligned}
$$

The function $\mathrm{F}\left(\mathrm{k}, \mathrm{s}, \mathrm{s}^{\prime}\right)$ appearing in (12) is defined by

$$
\begin{aligned}
F\left(k, s^{\prime}\right)= & \exp \left[1 k \sum_{n=4}^{\infty} c_{n}(s)\left(s^{\prime}-s^{\prime}\right)^{n}+\sum_{n=-1}^{\infty} \sum_{m=1}^{\infty} k^{-n / 3} \frac{v_{n}^{(m)}(s)\left(s^{\prime}-s\right)^{m}}{m !}\right. \\
& \left.-k^{I / 3} \dot{v}_{-1}(s)\left(s^{\prime}-s\right)\right] \sum_{n=0}^{\infty} \rho_{n}(s)\left(s^{\prime}-s^{\prime}\right)^{n} \sum_{n=-\infty}^{\infty} \beta_{n}(s, k)\left(s^{\prime}-s^{\prime}\right)^{n}
\end{aligned}
$$

In (13) $v_{n}^{(m)}(s)$ denotes the $m$-th derivative of $v_{n}(s)$.

To complete the asymptotic evaluation of the integral we introduce the new variable $t$ by means of the definftion

$$
s-s^{\prime}=e^{-i \pi / 6}\left(\frac{24}{k^{2}(s) k}\right)^{1 / 3} t .
$$

When (14) is used in (13), it shows that $F\left(k, s, s^{\prime}\right)$ has an expansion of the form 


$$
F\left(k, s^{\prime}\right) \sim 1+\sum_{n=1}^{\infty} k^{-n / 3} b_{n}(t, s)
$$

We next define $a(s)$ by the equation

$$
\dot{v}_{-I}(s)=a(s)(k(s))^{2 / 3}(24)^{-1 / 3} e^{i \pi / 6} .
$$

Finally we insert (14) - (16) into (12), which becomes

$$
I \sim i(3 / \pi)^{I / 2} \int_{0}^{\infty}+i / 2 e^{-a t-t^{3}}\left(I+\sum_{n=1}^{\infty} k^{-n / 3} b_{n}(t, s)\right) d t .
$$

Upon comparing coeficients of the various powers of $k$ in the asymptotic form of the integral equation (17), we obtain the following set of equations

$$
\begin{aligned}
& I-i(3 / \pi)^{1 / 2} \int_{0}^{\infty} t^{1 / 2} e^{-\alpha t-t^{3}} d t=0 \\
& \int_{0}^{\infty} t^{1 / 2} e^{-x t-t^{3}} b_{n}(t, s) d t=0, \quad n=1,2, \ldots
\end{aligned}
$$

From these equations we shall determine the coefficients $v_{n}(s)$.

W. Franz [6] has shown that the left side of (18) can be rewritten in terms of the Airy function A defined in equation (11) of section 2 . Thus (18) becomes 


$$
\frac{12}{\pi} e^{-i \pi / 6} A^{\prime}\left(-\frac{e^{i \pi / 3}}{4^{1 / 3}} \alpha\right) A\left(-\frac{e^{-i \pi / 3}}{4^{1 / 3}} a\right)=0 .
$$

The appropriate value of $a$ is determined by the vanishing of the A' factor in (20). If we denote by $q_{n}$ the roots of the equation $A^{\prime}\left(q_{n}\right)=0$, then the values $a_{n}$ of $x$ are given by

$$
a=a_{n}=-e^{i \pi / 3} 4^{1 / 3} q_{n}
$$

It will be useful to introduce the function $h(\alpha)$ defined by

$$
h(\alpha)=\int_{0}^{\infty} t^{-1 / 2} e^{-\alpha t-t^{3}} d t .
$$

Franz [6] has shown that

$$
h(\alpha)=4^{5 / 6} \sqrt{3 / \pi} A\left(-\frac{e^{i \pi / 3} \alpha}{4^{1 / 3}}\right) A\left(-\frac{e^{-i \pi / 3} \alpha}{4^{1 / 3}}\right) \text {, }
$$

and that $h$ satisfies

$$
h^{\prime \prime}(\alpha)=-\frac{1}{6} h(\alpha)-\frac{a}{3} h^{\prime}(\alpha) .
$$


To determine the consequences of (19) we must first compute the $b_{n}$ We shall calculate only $b_{1}$ and $b_{2}$. To do so we substitute (14) and (16) into (13), expand the exponential functions and multiply together the resulting series in powers of $\mathrm{k}^{-1 / 3}$. In this way we obtain

$$
\begin{aligned}
& b_{1}=e^{-i \pi / 6}(24)^{1 / 3} \frac{\dot{k}}{k^{5 / 3}}\left\{\left(\frac{-2}{3}-\dot{v}_{0} \frac{k}{\dot{k}}\right) t+\frac{a}{3} t^{2}+t^{4}\right\} \\
& b_{2}=\frac{3 e^{2 i \pi / 3} k^{2 / 3}}{8(24)^{1 / 3} t}-\frac{e^{-i \pi / 6}(24)^{1 / 3}}{k^{2 / 3}} \dot{v}_{1} t+e^{-i \pi / 3}(24)^{2 / 3} \\
& x\left\{\frac{t^{2}}{k^{4 / 3}}\left(\frac{\ddot{z}}{3 k}-\frac{k^{2}}{48}+\frac{\dot{x}^{2}}{24 k^{2}}\right)+\frac{2 a t^{3}}{3 k^{2}}\left(-\frac{\ddot{x}}{6 k^{1 / 3}}-\frac{13 \dot{k}^{2}}{36 k^{4 / 3}}\right)\right. \\
& \left.+\frac{a^{2} \dot{k}^{2} t^{4}}{13 k^{10 / 3}}+\frac{24 t^{5}}{k^{10 / 3}}\left(-\frac{2 \ddot{z}}{80}+\frac{k^{4}}{1920}-\frac{33 \dot{k}^{2}}{720}\right)+\frac{a^{2} t^{6}}{3 k^{10 / 3}}+\frac{\dot{k}^{2} t^{8}}{2 k^{10 / 3}}\right\} .
\end{aligned}
$$

When (25) is inserted into (19) an equation for $\dot{v}_{0}$ is obtained. This equation contains integrals of the form

$$
\int_{0}^{\infty} t^{n-1 / 2} e^{-\alpha t-t^{3}} d t=(-1)^{n_{h}(n)}(\alpha) .
$$

In (27) the integral has been expressed in terms of the $n$-th derivative of $h(\omega)$ which is defined by (22). Thus from (19) we find that the right hand side of (25) must vanish when $t^{n}$ is replaced by $(-1)^{n+l_{h}}(n+1)(a)$. This yields 


$$
\left(\frac{-2}{3}-\dot{v}_{0} \frac{k}{\dot{k}}\right) h^{\prime \prime}-\frac{\alpha}{3} h^{\prime \prime \prime}(\alpha)-h^{(y)}(\alpha)=0 .
$$

By using (24) we find that

$$
\begin{aligned}
& h^{(I V)}(\alpha)=-\frac{1}{2} h^{\prime}-\frac{\alpha}{3} h^{\prime \prime} \\
& h^{(V)}(\alpha)=\frac{\alpha}{18} h+\frac{\alpha^{2}}{9} h^{\prime}-\frac{5}{6} h^{\prime \prime}
\end{aligned}
$$

When (24) and (30) are used in (28), the following expression for $\dot{v}_{0}$ results

$$
\dot{v}_{0}=\frac{1}{6} \frac{\dot{k}}{k} .
$$

Upon integrating (31) we finally obtain for $v_{0}$ the expression

$$
v_{0}=\log k^{1 / 6}+\delta
$$

Here $\delta$ is an integration constant.

The analysis of (19) for the case $\mathrm{n}=2$ proceeds in exactly the same way. In this case we obtain the condition that the right hand side of (26) vanishes when $t^{n}$ is replaced by $(-1)^{n+1} h^{(n+1)}(a)^{\dagger}$. In order to simplify the resulting expression we must express the sixth through ninth derivatives of $h$ in terms of $h, h^{\prime}$, and $h^{\prime \prime}$. Upon doing this we find

$\dagger$ In order to avoid writing cumbersome equations we denote by $b_{2}{ }^{*}$ the right hand side of $(26)$ with $t^{n}$ replaced by $(-1)^{n+1} h^{(n+1)}(\alpha)$. 


$$
\begin{aligned}
& h^{(V I)}=\frac{7}{36} h+\frac{5 a}{9} h^{\prime}+\frac{a^{2}}{9} h^{\prime \prime} \\
& h^{(V I I)}=-\frac{a^{2}}{54} h+\frac{3}{4} h^{\prime}-\frac{a^{3}}{27} h^{\prime}+\frac{7}{9} \alpha h^{\prime \prime} \\
& h^{(V I I I)}=-\frac{\alpha}{6} h-\frac{7}{18} a^{2} h^{\prime}+\frac{55}{36} h^{\prime \prime}-\frac{a^{3}}{27} h^{\prime \prime} \\
& h^{(I X)}=\frac{a^{3}}{162} h-\frac{91}{216} h^{\prime}-\frac{157}{108} \alpha h^{\prime}+\frac{\alpha^{4}}{81} h^{\prime}-\frac{a^{2}}{2} h^{\prime \prime} .
\end{aligned}
$$

We also note that

$$
h "(\alpha)=-\frac{\alpha}{6} h(\alpha)
$$

This result follows upon differentiating (23) twice, then using the equation satisfied by $A(x)$

$$
A^{\prime \prime}+\frac{x}{3} A=0
$$

and finally noting that when $\alpha$ is defined by (21)

$$
A^{\prime}\left(\frac{-e^{i \pi / 3} \alpha}{4^{I / 3}}\right)=0 \text {. }
$$

We now insert the preceding relations for the derivatives of $h$, together with (3I) and (37) into $b_{2}^{*}$. We then find that the coefficient of $h^{\prime}$ vanishes and that the equation $b_{2}{ }^{*}=0$ may be solved to yield 


$$
\begin{aligned}
& \dot{v}_{1}=6(24)^{1 / 3} k^{2 / 3} a^{-1} e^{-i \pi / 6}\left\{\frac{k^{2 / 3}}{64}-\frac{1}{6 r^{4 / 3}}\left(\frac{1}{3} \frac{\ddot{k}}{k}-\frac{1}{48} k^{2}+\frac{1}{24} \frac{\dot{k}^{2}}{k^{2}}\right)\right. \\
&+\frac{a^{3}}{27 k^{2}}\left(\frac{\ddot{k}}{6 k^{1 / 3}}+\frac{13}{36} \frac{\dot{k}^{2}}{k^{4 / 3}}\right)+\frac{7 a^{3}}{648} \frac{\dot{k}^{2}}{k^{10 / 3}}+\frac{24}{k^{10 / 3}}\left(\frac{7}{36}-\frac{a^{3}}{54}\right) \\
&\left.\times\left(\frac{k \ddot{k}}{80}-\frac{k^{4}}{1920}+\frac{33}{720} \dot{k}^{2}\right)-\frac{4 a^{3}}{81} \frac{\dot{k}^{2}}{k^{10 / 3}}+\frac{1}{2} \frac{\dot{k}^{2}}{k^{10 / 3}}\left(\frac{29 \alpha^{3}}{324}-\frac{91}{216}\right)\right\}
\end{aligned}
$$

We next make use of (2I) of this section and (2I) of section 2 and set $k^{-I}=\mathrm{b}=$ the radius of curvature of $\mathrm{C}$. Then a straightforward calculation shows that (40) may be written as

$$
\begin{aligned}
\dot{v}_{1}= & \frac{i \tau^{2}}{30}\left(b^{-4 / 3}+\frac{16}{9} b^{-4 / 3} b_{S}^{2}-\frac{8 b^{-1 / 3}}{3} b_{S S}\right) \\
& -\frac{1}{20 \tau} n\left(2 b^{-4 / 3}+\frac{2}{9} b^{-4 / 3} b_{S}^{2}-\frac{b^{-1 / 3}}{3} b_{S S}\right) .
\end{aligned}
$$

Let us now combine our results (16), (21), (32), and (41). By inserting them into (5) we obtain the asymptotic expansion of $u(s)$ on the cylinder $\mathrm{C}$ up to and including terms in $\mathrm{k}^{-1 / 3}$.

$$
\begin{aligned}
\mathrm{u} \sim & \mathrm{E} \mathrm{b}^{-1 / 6}(\mathrm{~s}) \exp \left[i k s+1 \mathrm{k}^{1 / 3} \tau_{n} \int^{s} \mathrm{~b}^{-2 / 3}(\mathrm{~s}) \mathrm{ds}\right. \\
& +\frac{1 k^{-1 / 3}}{30} \tau_{n}^{2} \int^{s}\left(\mathrm{~b}^{-4 / 3}+\frac{16}{9} \mathrm{~b}^{-4 / 3} \mathrm{~b}_{\mathrm{s}}^{2}-\frac{8 \mathrm{~b}^{-1 / 3}}{3} \mathrm{~b}_{\mathrm{ss}}\right) \mathrm{ds} \\
& \left.-\frac{i \mathrm{k}^{-1 / 3}}{20 \tau} \int_{n}^{\mathrm{s}}\left(2 \mathrm{~b}^{-4 / 3}+\frac{2}{9} \mathrm{~b}^{-4 / 3} \mathrm{~b}_{\mathrm{s}}^{2}-\frac{\mathrm{b}^{-1 / 3}}{3} \mathrm{~b}_{\mathrm{ss}}\right) \mathrm{ds}+\ldots\right] .
\end{aligned}
$$


Here $\mathrm{E}$ denotes an arbitrary constant.

Let us now compare the result (42) with the expression for a mode given by the geometric theory of diffraction [5]. That theory yields for $u$ a single term of the sum in (33) of section 2. Let us insert into that equation the improved decay exponents (31) and diffraction coefficients (36). Then we find that each term of (33) coincides with (42) provided that the product of the constant coefficients in (33) is equated to the constant $E$ in (42). This agreement between the two methods of obtaining the improved decay exponents and diffraction coefficients again confirms the results of section 2. The method of the present section can also be modified to apply to soft cylinders, on which $u=0$. 
Appendix

In order to calculate the quantity $r\left(s, s^{\prime}\right)$ in the neighborhood of $s=s^{\prime}$ we first observe that if $\vec{x}(s)$ is the position vector to the curve C, then

$$
r^{2}=\left(\vec{x}(s)-\vec{x}\left(s^{\prime}\right)\right)^{2}
$$

By Taylor's theorem

$$
\vec{x}\left(s^{\prime}\right)-\vec{x}(s)=\sum_{n=1}^{\infty}\left(s^{\prime}-s\right)^{n} \frac{\vec{x}^{(n)}(s)}{n !} .
$$

Thus, upon taking the dot product of (2) with itself we find

$$
r^{2}=\sum_{\rho=2}^{\infty}\left(s^{i}-s\right)^{\rho} b_{\rho} .
$$

Here

$$
b_{\rho}=\sum_{n=1}^{0-1} \frac{\vec{x}^{(n)}(s) \cdot \vec{x}^{(p-n)}(s)}{n !(p-n) !}
$$

Slnce $s$ is arclength along $C$ we have

$$
\vec{x}(s) \cdot \vec{x}(s)=1
$$

and

$$
\overrightarrow{\vec{x}}(\mathrm{~s}) \cdot \overrightarrow{\mathrm{x}}(\mathrm{s})=0 \text {. }
$$


From the Frenet equations of differential geometry we have

$$
\ddot{\vec{x}}(s)=\dot{k} k-1 \ddot{\vec{x}}-k^{2} \dot{\vec{x}}
$$

Upon using (5), (6), and (7) recursively to obtain the higher derivatives of $\vec{x}(s)$ in terms of $\dot{\vec{x}}(s)$ and $\vec{x}(s)$ we see that $b_{\rho}$ can be expressed in terms of $k$ and its derivatives. In this way we find

$$
b_{2}=1 ; \quad b_{3}=0 ; \quad b_{4}=-\frac{k^{2}}{12} ; \quad b_{5}=-\frac{k \dot{k}}{12} ; b_{6}=-\frac{1}{45} \dot{K}^{2}-\frac{1}{40} k \ddot{k}+\frac{k^{4}}{360} \text {. }
$$

Then upon taking the square root of the right hand side of (3) we find

$$
r=\sum_{n=1}^{\infty} e_{n}\left(s-s^{\prime}\right)^{n}
$$

Here

$$
c_{1}=b_{2} ; \quad c_{2}=b_{3} ; \quad c_{3}=\frac{b_{4}}{2} ; \quad c_{4}=\frac{-b_{5}}{2} ; c_{5}=\left(\frac{b_{6}}{2}-\frac{b_{4}^{2}}{8}\right) .
$$

From (8) and (10) the entries for $c_{n}$ in Table I are obtained.

In order to calculate $r^{-1 / 2} \partial r / \partial n^{\prime}$ we note that the unit normal to C at $s^{\prime}$ is $k^{-1}\left(s^{\prime}\right) \dot{\vec{x}}\left(s^{\prime}\right)=\vec{v}_{2}\left(s^{\prime}\right)$ and hence

$$
\frac{\partial r}{\partial n}=\nabla(\vec{r}) \cdot \vec{v}_{2}\left(s^{\prime}\right)=\frac{\vec{r}_{0} \cdot \vec{v}_{2}\left(s^{\prime}\right)}{r}
$$

Thus by making use of (2) and the Taylor expansion of $\vec{v}_{2}\left(s^{\prime}\right)$ about $s=s^{\prime}$ we obtain 


$$
r \frac{\partial r}{\partial n^{\prime}}=\sum_{\rho=1}^{\infty}\left(s^{\prime}-s\right)^{\rho} f_{\rho} .
$$

Here

$$
f_{\rho}=\sum_{k=1}^{p} \frac{\vec{x}^{(k)}(s) \cdot \vec{v}_{2}^{(\rho-k)}(s)}{k !(\rho-k) !} .
$$

Again upon using the Frenet equations recursively the coefficients $f_{\rho}$ may be easily evaluated to obtain

$$
f_{1}=0 ; \quad f_{2}=-\frac{k}{2} ; f_{3}=-\frac{\dot{K}}{3} ; f_{4}=-\frac{\ddot{K}}{8}+\frac{k^{3}}{24} .
$$

Now by applying the binomial theorem to (3) we find

$$
r^{-3 / 2}=\left(s-s^{1}\right)^{-3 / 2}\left(b_{2}-\frac{3}{4} b_{4}\left(s-s^{1}\right)^{2}+\frac{3}{4} b_{5}\left(s-s^{1}\right)^{3}+\ldots\right) .
$$

Thus upon multiplying (15) and (12) we find

$$
r^{-l / 2} \frac{\partial r}{\partial n},=-\frac{k(s)}{2}\left(s-s^{1}\right)^{1 / 2} \sum_{n=0}^{\infty} \rho_{n}(s)\left(s-s^{1}\right)^{n}
$$

where

$$
\rho_{0}=1 ; \quad \rho_{1}=\frac{2 f_{3}}{\kappa} ; \quad \rho_{2}=-\frac{2 f_{4}}{\kappa}-\frac{3}{4} b_{4} .
$$

Thus from (8), (14), and (17) we obtain the values of $\rho_{n}$ given in Table I. Upon using (9) and the values of $(0, m)$ given in section 4 it is a simple matter to calculate the values of $\beta_{0}$ and $\beta_{-1}$ as given in Table $I$ and to conclude that $\beta_{n}\left(s^{\prime} s^{1}\right)^{n}=O\left(k^{-2 / 3}\right)$ for $n \neq 0,-1$ and $s^{-s^{\prime}}=O\left(k^{-1 / 3}\right)$. 
[1] Watson, G. N.

[2] Bremmer, H.

[3] Franz, W. and Depperman, K.

[4] Keller, J.B.

[5] Keller, J. B.

[6] Franz, W.

[7] Levy, B. R., and Keller, J.B.

[8] Rice, S. O.,

[9] Levy, B.R.

[10] Kazarinoff, N. D. and Ritt, R. K.
'The diffraction of electric waves by the earth and the transmission of electric waves around the earth', Proc. Roy. Soc. (London), Vol. A95, pp. 83-99, Oct. 1918, pp. 546-563, July 1919.

'Terrestrial Radio Waves', Elsevier Publishing Co., New York, N.Y.

'Theorie der Beugung am Zylinder unter Berucksichtigung der Kriechwelle', Ann. der Phys., Vol. 10, No. 6. pp. 361-373, 1952 .

'A geometric theory of diffraction', Calculus of Variations and its Applications, Proc. of Symposia in Applied Math., Vol. VIII, pp. 27-52, McGraw-HilI, New York, N.Y., 1958.

'Diffraction by a convex cylinder', I.R.E. Trans. on Ant. and Prop., Symp. on Electromagnetic Wave Theory, Vol. Ar-4, pp. 312-321, July 1956.

'Uber die Greenschen Funktionen des Zylinders and der Kugel', Ze1t. fur Naturf., Vol. 9a, pp. 705-716, 1954.

'Diffraction by a smooth object', Comm. Pure and Appl. Math., 12, No. 1, 159-209, 1959.

'Diffraction of plane radio waves by a parabolic cylinder', Bell Sys. Tech. J., Vol. 33, pp. 417-502, March 1954.

'Diffraction by an elliptic cylinder', New York Univer., Inst. of Math. Sci., Div. of EM Res., Res. Report No. FM-12l, (1958).

'Scalar Diffraction by an elliptic cylinder', Univer. of Michigan, Res. Inst., Scientific report. 
[II] Levy, B. R. and Keller, J. B.

'Diffraction by a spheroid', New York Univer., Inst. of Math. Sci., Div. of FM Res., Res. Report No. FM-130(1959

[12] Ritt, R. K. and Kazarinoff, N. D. 'Studies in radar cross sections XXX, The theory of scalar diffraction with application to the prolate spheroid', Univer. of Michigan Res. Inst., Scientific Report No. 4, 1958.

[13] Olver, F. W. J.

'The asymptotic solution of linear differential equations of the second order for large values of a parameter', Ph1l. Trans. Roy. Soc. of London, Series A, 247, pp. 307-368(1954. 

(ONE copy tunless otherwise noted)

Commander

A1r Research and Davelopment Command

Andrews $\mathrm{A} 1 \mathrm{r}$ Force Base

Washington 25, D. C.

4ttn: Major E. Wright, RDTCC

D1rector of Resident Training $3380 t h$ Technical Trainling Group

Keesler Afr Forca Base, Mississippl

Attn: OA-3011 Course

D1rector

Air University Library

Maxwell Air Force Bage, Alabama

Commander

Air Force Misails Test Center

Patrick Air Force Base, Florida

Attni MTS - for classified documents

Attn: MU-411, Technical Library - for unclassified documents

Tactical A1r Group

D1rectorata of Research and Davelopment DCS/D Heedquarters, USAF

Washington, D. C.

Director, Communtcations and Electronles Hq. U. S. Alr Force

Washington 25, D. C.

4ttn: AFOAC $S / E$

Commander

Wright Air Development Center

Wright-Patterson Air Force Base, Onlo

Attn: WCLRS-6, Mr. Portune

Wright A1r Development Center

Wright-Patterson Air Force Base, Ohlo

Flight Resarch Laboratory

Regearch Division

Attn: WCRRA

Commanter

Wright Air Development Center

Wright-Patterson Air Force Bese, Ohio

Attna N. Draganjac, WCLNQ-L

Commander

Wright A1r Davelopment Center

Wright-Fatterson Alr Force Base, Ohio

Attnt Mr. Paul Springer. WCLPE-5

Commanier

A1r Technical Intelligenca Centar

Wright-Fattoraon Air Force Base, Oh1o

Attn: $A \cap C I N-4 B i a$

Commander

Rome Air Development Center

Griffiss A1r Force Base, New York

Attn: RCSSTL-1

Comenander

Rome A1r Development Center

Griffiss Air Force Base, New York

Attn: Mr. Donald Dakan, RCUE

\section{Comandar}

Rome A1r Davelopment Center (ARDC)

Griffios Air Porca Base, New York

Attri Dr. John S. Burgess, RCE

Commender

Air Force Missile Dovelopmant Center

Holloman A1r Force Base, Naw Mexico

Attn: HDNI, Technical L1brary

Director

U. S. Arry Ordnance

Ballistic Research Leboratorles

Aberdeen Proving Ground, Marvland

Attn: Ballistic Measurements Laboratory

Ballist1c Ressarch Laboratorlea

Aberdean Proving Ground, Maryland

Attn: Technical Information Branch
Director

Evans Signal Laboretory

Belmar, Now Jersey

Attn: Mr. O. C. Woodyard

v. S. Amay Signal Engineering Labs. Evans Signel Laboratory

Belnar, New Jersey

Attn: Technical Document Center

Massachusetts Institute of Technology

Signal Corps Liaison Officer

Cambridge 30, Mass.

Attn: A. D. Bedrosian, Room 26-131

Commanding General, SIGFM/EL-PC

U. S. Ariny Signal Engineering Labs.

Fort Monmouth, New Jersey

Attint Dr. Horst H. Kedesdy Deputy Chlef, Cham-Physics Pranch

Commanier

Army Rocket and Guided Missile Agencp

Redstone Arsenal, Alabama

Attn: Technical Library, ORDXR-רTL

Commanding General

v. S. A rmy Signal En ingering Labs.

Fort Monnouth, New Jersey

Attn: SIGFM/EL-AT

Department of the Army

office of the Chief Signal officer

Washington $25, D$. C.

Attn: SIGPD-7

Office of Chief Signal officer

Engineering and Technical Division

Washington 25, D. C.

Attn: SIGNET-5

Guided Missile Fuze Library

Diamond Ordnance Fuze Latoratories

Washington 25, D. C.

Attn: R. D. Hatcher, Chief Microwave Development Section

(10)Armed Services Technical Information Agency

Arlington $\mathrm{Hall}$ Station

Arlington 12, 7irgin18

(2)Library

Boulder Laboratories

National Burean of Standarda

Boulder, Colorado

National Bureau of Standards

Departinent of Commerce

Washingt on 25, D. C.

Attn: $\mathrm{Mr}$. A. G. McNish

National Bureau of Standards

Department of Commerce

Washington 25, D. C.

Attn: Sustave Shapiro, Chief

Engineering Electronics Section

Electricity and Electronlcs Div.

(2) Oifice of Tachnical Serfices

Department of Commerce

Washington 25, D. C.

Attns Technical Renorts Section (Unclassifled only)

\section{Director}

National Security Agency

Washington 25, D. C

Attn: $R / D$ (33i)

(2) Ho. Air Force Cambridge Resaarch Center Laurence G. Henscom Fleld

Bedford, Mass.

Attna CROTLR-2 - P. Condon

(5) Hq. Air Force Cambridge Research Center Laurence C. Hanscom Field

Bedford, Mass.

Attnt CROTLS - J. Armstrong
(5) Hq. A1r Force Cambridge Research Centor Laurence $G$. Hanscom Fleld

Bodford, Mass.

Attn: CRRD

Director, Avionics Division (AV)

Bureau of Aeronautics

Department of the Navy

Washington $25, D$. C.

Chiaf, Bureau of Ships

Deportment of the Navy

Weshineton 25, D. G.

Attn: Mr. E. Johnston, Code $833 \mathrm{E}$

Commander

V. S. Naval A1r Missile Tegt Center

Point Mugu, Californie

Attn: Code 366

U. S. Naval Ordnance Laboratory

White Oak

Silver Sprine 1\%, Maryland

Attn: The Library

Comnander

U. S. Naval Ordnance Test Station

Chlna Lake, California

Attn: Code 753

Librarian

U. S. Naval Poatgraduate School

Montarey, Californte

Air Force Developmant Field Reprasantative Naval Research Laboratory

Washington 25,0 . C.

Attn: Cods 1072

Director

V. S. Naval Research Laboratory

Washington 25, D. C.

Attn: Code 2027

Dr. J. I. Bohnert, Code 5210

v. S. Naval Research Loboratory

Washington 25, D. C. (Unclassified onlys

Classified to sent to:

Director

U. S. Naval thesearch Lahoratory

Attn: Code 5200

Washington 25, D. C.

Commanding officer and Director

U. S. Navy Underwater Sound Lahoratory

Fort Trumbull, New London, Connecticut

Chief of Naval Research

Department of the Navy

Kashington 25, D. C.

Attn: Code 427

Commanding Orficer and Director

0. S. Navy Electronica Laboratory (Library)

San Dlego 52, Californta

Chief, Bureau of Ordnance

Department of the Nay

hashingt on $25, \mathrm{D}, \mathrm{C}$.

Attn: Code Ad3

Chief, Bureav of Ordnance

Department of the Navy

Surface Guided Missile Branch

Washington $25, \mathrm{D}$. C.

Attn: Coda Rasi-e

Chlef, Bureau of Ordnance

Department of the Navy

Washington 25, D. C.

Attn: Fire Control Branch (RaSt)

Department of the Navy

Burear of Aaronautica

Technical Data Divialon, Cade 4106

Washington $25, D$. C.

Chitef, Buresu of Shipe

Department of the Navy

washington 25, D, C.

Attn: Code 817B 
Comanding officer

J. S. Naval Air Development Center Johnsollie, Pensyluania

Attn: NADC Library

Comander

V. S. Naval Air Test Center

Patuxent R1ver, Maryland

Attn: ET-325, Antenna Branch

Director

Naval Ordnance Laboratory

Corona, California

Comanding officer

U. S. Napal Ordnance Laboratory

Corona, Celifornta

Attn: Mr. W. Horenstein, Division 72

Airborne Ingtruments Lahoratory, Inc. t to old Country Road

Mineols, New York

Attn: Dr. E. G. Fubini, Director Rasearch and Engineering Division

Aircom, Inc.

35) Main Street

Winthrop, Mass.

American Nachine and Foundry Company Electronics Division

ICAS Commonwealth Avenue

Boston 15, Mass.

Attn: Mrs. Rita Moraveaik, Librarian

Andrew Alford, Consulting Engineers

299 Atlant 1C Avenue

Boston 10, Maaa.

Avion Division

ACF Industries, Inc.

800 No. P1tt Street

Alexandria, $\nabla 1 \mathrm{rginis}$

Attn: Library

Battelle Memorial Institute

$505 \mathrm{~K} 1 \mathrm{ng}$ A venue

Attn: Waym E, Rife, Project Leader

Electrical Engineering Division

Columbua 1, Ohio

Bell Alreraft Corporation

Post office Box One

Buffalo 5, New York

Attn: Eunice P. Hazelton, Librarian

Bell Telephone Laboratories, Inc.

Whippany Laboratory

Whippany, New Jersey

Attn: Technical Information Library

Pacific Division

Bendix Aviation Corporation

11600 Sherman Way

North Hollywood, Californta

Engtneering Library

Attn: Peggie Robingon, Librarian

Bendix Radio Division

Bendix Aviation Corp.

F. Joppa Rosd

Towgon L, Maryland

Attn: Dr. D. M. Alligon, Jr. D1rector Englneering and Resaarch

Boeing Airplane Company

Pllotlesa Alrcraft Division

P.C. Box 3707

Seettle 24, Washington

Attn: R.R. Barber, Library Supervisor

Boolng Airplane Company

Wichit Division Enginaering Library

Wichits 1, Kansas

Attn: Kenneth C. Knight, Librarian

Boeing Airplane Company

Seattle Division

Seattle 1h, Warhington

Attn: E.T. Allen, Librarv Supervioor

Bjorksten Regearch Labs, Inc.

P. 0. Box 265

Madison, Wlaconsin

Attn: Mrs. Fern B. Korggard
Convair, A Division of General Dymanics Corp.

Fort Worth, Texas

Attn: K.G. Brown, D1vision Rasearch Librarian

Convair, A Division of General Dynamics Corp.

San Diego 12, California

Attn: Mrs. Dora B. Burle,

Engineering Lfbrarian

Cornell Aeronautical Laboratory, Inc.

L455 Geneaee Streot

Buffalo 21, New York

Attin: Lubrarian

Dalmo Victor Company

A Division of Textron, Inc.

1515 Industrial Way

Belmont, Californta

Attn: Mary Ellen Addems,

Technical Librarian

Dorne and Margolin, Inc.

29 New York A venue

Westbury, Long Igland, N. Y.

Douglas Aircraft Company, Inc.

P. . Box 200

Lon Besch 1, Californis

Attn: Englnaering Library (C-250)

Douglag Aircraft Co., Inc.

R27 Lapham Street

El Sagundo, Californio

Attn: Engineering Library

Douglas Aircraft Company, Inc.

3000 Ocean Park Boulevard

Sant a Monica, California

Attn: P.T. Cilne

Ea. Sec. Reference Files,

Eq. Eng. A250

Douglas Afreraft Company, Inc.

2nno North Memorial Drive

Tulga, Oklahoma

Attn: Engineering Library, D-250

Electronics Communication, Ine.

1830 York Road

Tymonivm, Marvlend

Emeraon and Cuming, Inc.

\&69 Waahington Street

Canton, Maga.

Attn: Mr. W. Cuming

Enerson Electric $\mathrm{Mfg}$. Co.

8100 West Florissant Avenue

St. Louis 21, M1ssour1

Attn: Mr. E.R. Breglin, Librarian

Sylvania Elec. Prod. Inc.

Electrontc Defenge Laboratory

P.C. Box 205 - (Uncl)

Mountain Viaw, Californda

Attn: Lfbrary

Fairchild Aircrsft Divieion

Fairchild Eng, and Airplane Corp.

Hagerstown, Maryland

Attn: Library

Farngworth Electronics Company

3700 East Pontiac Street

Fort Wayne 1, Indiana

Attn: Technical Library

Federal Telecommuntcation Laba.

500 Waghingt on A venue

Nutley 10, Now Jersey

Attn: Technical Library

The Gabrisl Electrontcs

Division of the Gabriel Company

135 Crescent Road

Needham Helghts 9h, Mass.

Attit Mr. Steven Galagan
Genaral Electric Advanced Electronica Center

Cornell University

Ithaca, Naw York

Attn: J. B. Travis

General Electric Company

Electronics Park

Syracuse, New York

Atin: Documents Library, B. Fletcher Building 3-il 3 A

General Pracision Laboratory, Inc.

63 Bedford Road

Pleasantville, New York

Attn: Mrg. Mary G. Herbst, Librarian

Goodvear Aircraft Corp.

1210 Masailion Road

Akron 15, Ohio

Attn: Lubrary D/120 Plant A

Cranger Associates

Electronic Systemi

966 Commercial Street

Palo Alto, Californi

Atti: John V. N. Granger, President

Grumman Aircraft Engl neering Corporation

Bethpage, Long Ialand, N. Y.

Attn: Mrs. A. M. Crav, Librarian Engineering Library, Plant No. 5

Tha Rallicraftars Company

$4 \mathrm{~h} 01$ West $5 \mathrm{th}$ Avenue

Chicago 24, IIlinols

Attn: LaVerne LaGioia, Librarian

Hof $\mathrm{man}$ Laboratories, Inc.

376.1 South Hill Street

Los Angeles?, California

Attn: Enginaering Library

Hughes A1rcraft Company

Antenna Dopartment

Microwave Iaboratory

Building 12, Room 2617

Culver City, Californis

Attn: M. D. Adeock

Hughea Aircraft Company

Florence and Teale Stroet

Culver City, California

Attn: Dr. L.C. Van Atta, Associate Director Research labs.

Hycon Eagtern, Inc.

75 Cambridge Parkway

Cambridge, Maes.

Attn: Mre. Lois Seulowitz Technical Librarian

Intermational Business Machines Corp. Military Products Diviaion

590 Madison A venue

New York 33, New York

Attn: Mr. C.F. McElwain, Genersl Manager

Intarnational Bugineas Machines Corp.

Military Products D1 vision

Owego, NaH York

Attn: Mr. D. I. Marr, Lihrarian Department 459

International Realatance Company

401 N. Broad Street

Philadelphis 8, $\mathrm{Pa}$.

Attn: Resesrch Library

Jansky and Bailey, Inc.

1339 Wisconsin A venue, N. W.

Washington 7, D. C.

Attn: Mr. Dalmer C. Porta

Dr. Hanry Jagik, Consulting Engineer

298 Shanes Drive

Brugh Hollow Indugtrial Park

Westbury, New York

Electromagnetic Research Corporation

711 lith Street, N. W.

hashington 5, D. C. 
Lockhead Afrcraft Corporation $2555 \mathrm{~N}$. Hollywood way California Diviaton Engineering Library Department 72-75, Plant A-1, Bldg. 63-1 Burbank, Callfornia Attn: N. C. Harnols

The Martin Company

F. O. Box 179

Denver 1, Colorado

Attn: Mr. Jack McCormick

The Glenn L. Martin Company Baltimore 3, Maryland Attn: Englneering Library Antenna Design Group

Marvland Electrontc Manufacturing Corp. 5009 Calvert Road

Collage Park, Maryland

Attn: Mr. H. Warren Cooper

Mathematical Reviewa

190 Hope Street

Providence 6, Rhode Island

The W. L. Maxson Corporation

460 West 3 lth Street

New York, N. I.

Attn: Miss Dorothy Clark

McDonnell A1reraft Corporation

Lambert Saint-Louls Municipal Airport

Box 516, St. Louls 3, Missour1

Attn: R. D. Detrich, Engineering Library

McMillan Laboratory, Inc。

Erownville A venue

Ipswich, Massachusetts

Attn: Security officer, Document Room

Melpar, Inc.

3000 Arlington Bovlevard

Falls Church, Virginia

Attn: Engineering Technical Liorary

Microwave Development Laboratory

90 Broad Street

Babson Park 57, Masaachusetts

Attn: N. Tucker, General Manager

Microweve Radiation Compeny Ine.

19223 South Ham1lton Streat

Gardens, Californte

Attn: Mr. Morris J. Ehrlich, President

Chance Vought Aircraft, Ino.

9314 West Jefferson Straat

Dajlas, Texas

Attn: Mr. H. S. White, Lihrarian

Northrop Aircraft, Inc.

Hawthorne, Californta

Attn: Mr. E. A. Freitas, Library Dept 3145 $1001 \mathrm{E}$. Broadway

Remington Rand Univ. - Division of Sperry

1900 West Allogheny Avenue Rand Corporation

Ph1ladalphia 29, Pennsyl vant

Attn: Mr. John F. McCarthy $\mathrm{R}$ and D Salea and Contracts

North American Aviation, Inc.

12214. Lakewood Boulavard

Downey, Cal1forn1s

Attn: Englneering Library 495-115

North American A viation, Iac.

Los Angeles International Airport

Los Angeles 15, Californis

Attn: Entinearing Techntcal File

Page Communications Enginears, Inc.

710 Fourteanth Street, Northwest

Wa shington 5, D. C.

Attn: Librarian

Philco Corporation Research Division

Branch Library

4700 Wissachickon Avenue

Philadel phia Wh, $\mathrm{Pa}$.

Attn: Mrs. Dorothy S. Colling
Plckard and Burns, Inc.

$2 \mathrm{l}, \mathrm{O} \mathrm{H} 1 \mathrm{ghl}$ and Avemue

Needhan 94, Masa.

Attn: Dr. J. T. DeBettencourt

Polytechnfc Research and Development Company, Inc.

202 T1llary Street

Brooklyn 1, New York

Attn: Techntcal Library

Radiation Engl neering Laboratory

Majn St reet

Maynerd, Mass.

Attn: Dr. John Ruze

Radiation, Inc.

P. 0. Drawer 37

Melbourne, Flortio

Attn: Technical Library, Mr. M.L. Cox

Radio Corp. of America

RCA Laboratories

Rocky Foint, New York

Attn: P. S. Carter, Lab. Library

RCA Laboratories

David Sarnoff Research Canter

Princeton, New Jersey

Attnt Miss Fern Cloak, Librarian Research Library

Radio Corporation of America

Defense Elactrontc Projucts

Bullding 10, Floor?

Camden 2, New Jersey

Attni Mr. Harold J. Schrader Staff Engineer, Organization of Chief Technical Administrator

(2) The Ramo-Wooldridge Corporation P. . Box 45453 A1rmort Station

Los Angeles 45, Californis

Attn: Margaret C. Whitnah, chief Librarian

Hoovar Microwave Co.

9592 Baltimore Avenue

College Park, Marvland

Director, USAF Project RAND

V1a: Afr Force Lialson of fice

The Rand Corporation

1700 Main Street

Sant a Monica, Cal1fornta

Rantec Corporation

Calabasaa, Cal1fornia

Attn: Grace Keener, Office Managar

Raytheon Msnufacturing Company

Misile Systems Division

Bedford, Mass.

Attn: Mr. Irving coldstein

Raytheon Manufacturing Company Wayland Laboratory, State Rad Wayland, Mass.

Attn: Mr. Robert Borts

Raytheon Manufacturing Comnany Wayland Laboratory

Wayland, Masa.

Attn: Miss Alice G. Anderson, Librarian

Rapublic Ariation Corporation

Farmingdale, Long Island, N. Y.

Attn: Engineering Lihrary

Thru: A1r Force Plant Representative Republic Aviation Corp. Farmingdale, Long Island, N.Y.

Rheem Manufacturing Company

9236 East Hall Road

Douney, Cal1fornia

Attn: j. C. Joerger

Trana-Tech, Inc.

P. 0. Box 346

Freder1ck, Maryland
Pyan Aeronautical Comnany

Indhergh Field

San J1ego 12, Californis

Attn: Library - unclassifled

Sage Laboratories

159 Linden Street

Wellesley 81 , Mass.

Santers Associatios

95 Canal Street

Nashua, New Mampshire

Attn: N. R. W1ld, Library

Sandia Corporition, Sandia Haso

P.O. Box 5Roo, Albu zuer zue, New Mexico

Attn: Classified Document Division

Spermy Gyroacope Company

Great Neck, Long Island, New York

Attn: Florence W. Turnbull, Engr. Librarian

Stanf ord Research Institute

Menlo Park, Californla

Attri Library, Englnaering Division

Sylvania Electric Products, Inc.

ino First A veme

Walthan 5l, Nass.

Attn: Charles A. Thornhill, Report Librarian Waltham Lahoratorles Ifbrar

Systems Lahorator1es Corporation

14. 952 Ventura Boulevard

Sherman Jaks, Califormis

Attn: Donald L. Margerum

TRO, Inc.

17 Union Square Wast

New York 3, N. Y

Attn: M. L. Henderson, Librarian

A. S. Thomes, Ine.

161 Devonshire Stroet

Boston 10, Mass.

Attr: A. S. Thomas, President

Bell Talaphone Laborat orles

Murray H111

Naw Jersey

Chu Associatas

P. O. Box 3A7

Whitconb Avenue

Litileton, Mass.

Microwave Asgociates, Inc.

Burlineton, Mass.

Raytheon Manufacturing Company

Missile Division

Hartwell Rasd

Badford, Mass.

Radio Corporation of America

Aviation Systems Laboratory

225 Crascent Stregt

walthan, Mass.

Lockhaed Alrcraft Corporation

Misalle Systems Division Pasearch library

Box 504, Sunnyvala, California

Attn: Miss Eva Lou Robertson, Chief Librarian

The Rand Corporation

1700 Main Street

Santa Monica, Callfornia

Attn: Dr. W. C. Hof fman

Commander

AF Office of Sclentific Research

A1r Resaarch and Developmant Command

1 ith Streat and Constitution A venue

Washington, D. C.

Attn: Mr. Otting, SRY

Westinghouse Electric Corp.

Electrontes Division

Friendship Int "l Airport Box 71,6

Baltimore 3, Maryland

Attn: Engineering library 
Wheeler Laboratories, Inc.

122 Cutter M1ll Road

Great Neck, New York

Attn: Mr. Harold A. Wheelar

Zenith Plagtics Ca.

Box 91

Garjena, Californis

Attri: Mr. S. S. Oleasky

Library Geophysical Institute

of the University of Alaska

College

Undvergity of Califoinda

Perkeley 4, Californía

Attn: Dr. Samuel Silver,

Prof. Engineering Science

Division of Elec. Eng. Electronics Research Lab.

Iniversity of California

Electronics Research Lab.

332 Corv Hall

Rerikeley L, Caltrornia

Attn: J. R. Whinnery

California Institute of Technolagy

Jet Propulaion Laboratory

LAOO Oak frove Drive

Pasatena, Calif ornta

Attn: Mr. I. E. Newlan

California Institute of Technology

1201 E. Californi a Street

Pasadena, Californta

Attn: Dr. C. Papas

Cernagie Institute of Tachnology, Schenley Park

Pittsburgh 13, Pennsylvanta

Atto: Prof. A. E. Heins

Cornell University

School of Elactrical Enginearing

Ithaca, New York

Attn: Prof. G. C. Delman

I'nivergity of Florida

Department of Electrical Englneoring

Gaines ville, Florida

Attn: Prof. M. H. Latour, Library

Lihnary

Georgia Institute of Technology

Engineering Experiment Station

Atlante, Georgla

Attn: Mrs. J.H. Crosland, Librarian

Harvard Unfveraity

Technical Reports Collection

Gordon McKay Library, 303A Plerce Hall

Oxford Street, Cambridge 3R, Mass.

Attn: Mrs. E.L. Hufschmidt, Librarian

Harvard College Obsarvatory

(6) Garden Street

Cambridge 39, Mass.

Attn: Dr. Fred L. Whippla

Iniveraity of Illinois

Document a Divion Library

Urbana, Illinals

University of Illinols

College of Engineering

Urbana, Illinols

Attn: Dr. P. E. Moyes, Department of Electrical Engineering

The Johns Hopkins University

Homewood Campus

Department of Physice

Baltimore 18, Maryland

Attn: Dr. Donald E. Kerr

Sandia Corporation

Att, n: Organization 1423

Sandia Basa

Albu zuerque, New Mexico
Applied Pnysies Laboratory

The Johf Hopkins Uni versity

8621 Georgia A venue

Silver Spring, Maryland

Attn: Mr. George L. Selelstad

Massachugetts Institute of Technology Research Laboratory of Electronies

Room 20B-221

Cambridge 39, Massachusetts

Atto: John H. Hewltt

Massachusetts Institute of Technolagy Lincoln Laboratory

P. 0. Box 73

Lexington 73, Mass.

Attn: Document Room $\mathrm{A}-229$

University of Michigan

Electronic Defense Group

Engineering Research Institute

Ann Arbor, Michigan

Attn: J. A. Boyd, Supervisor

University of Michigan

Engineering Research Institute

Radiation Laboratory

Atts: Frof. K. M. Siegel

912 N. Main St.

Ann Arbor, Michígas

University of Michigan

Engineertng Research Institute

Willow Run Laboratories

W11low Run Airport

Ypsilant 1, Michigan

Attn: Itbrarian

"niversity of Minnesota

Minneapolis 14, Minnesota

Attn: Mr. Robert H. Stumm, Library

Northwestern University

Mi crowa ve Laboratories

Evanston, Illinois

Attn: R. E. Beam

Ohio State University Research Found.

Oh1o State Universit

Columbus 10 , Ohia

Attni Dr. T.E. Tice

Dept. of Elec. Engineering

The Untrersity of Oklahoma

Research Inst1tute

Nortian, Oklahome

Attni Prof. C. L. Farrar, Chairman Electrical Engineering

Polytachnic Institute of Brooklyn

Microwave Research Institute

55 Johnson Stret

Brooklyn, New York

Attn: Dr. Arthur A. Oliner

Polytechnic Institute of Brooklym Mi rowave Rasearch Institute

55 Johnson Street.

Rrooklyn, New York

Attn: Mr. A. E. Inemmel

Syracuse University Research Institute Collendale Campus

Syracuse 10, New York

Attn: Dr. C. S. Grove, Jr. Director of Engineering Research

The Univeraity of Texas

Elec. Engl neering Research Laboratory

P. 5. Box 8026, Unt versity Station

Austin 12, Texas

Attn: Mr. John R. Gerhardt

Assistant Director

The Untversity of Texas

Dafense Research Laboratory

Austin, Texss

Attn: Claude W. Hortan, Physics Ltbrary

Univeralty of Toronto

Department of Electrical Enginearing

Toronto, Canada

Attn: Prof. G. Sinclair
Lowell Technolopical Institute

Rasearch Foundation

P. 0. Box 709, Lowell, Mass.

Attn: Dr. Cherles R. Minglns

Unf versity of Washington

Department of Elactrical Engineering

Seattle 5, hasinington

Attn: C. Held, Associate Professor

Stanford Uni veraity

Stanford, California

Attn: Dr. Chodorat

Microwave Laboratory

Physicel Science Laboratory New Mexico College of Agriculture and Machanic Arts

State College, New Mexico

Attn: Mr. H. W. Haas

Brown University

Department of Electrical Engineoring

Providence, Rhode Island

Attn: Dr. C. M. Angulo

Case Inst1tute of Technology

Cleveland, Ohio

Attn: Frof. S. Seeley

Columbia University

Department of Electrical Engineering

Morningside Heights

New York, N. Y

4ttn: Dr. Schlasinger

McGill Univeraity

Nontreal, Canada

Attn: Pror. G. A. Woonton

Director, The Eaton Electronics Research Lab.

Purdue University

Department of Electrical Engineering

Lafayette, Indiane

Attn: Dr. Schulta

The Pennaylvania State University Department of Electrical Enginaering Un'versity Park, Pennsylvanie

Un1 versity of Pennsvlvania

Institute of Conperative Research

3400 Walnut Street

Philadelphia, Pennsyl vania

Attn: Dept. of Electricsl Engineering

University of Tennessee

Farris Hall

W. Cumberland A venue

Knoxville 16, Tennesses

Unf versity of Wisconsin

Department of Electrical Engineering

Madison, Wisconsin

Attn: Dr. Scheibe

University of Seattio

Department of Electrical Engineering

Seatt $1 \theta$, Washington

Attn: Dr. D. K. Reynolds

Wayne Unt versity

Detroit, Michigan

Attn: Prof. A. F. Stevensan

Electronics Research Laboratory

Illinois Institute of Technology

3300 So. Federal Stret

Chicago 16, Illinois

Attn: Dr. Lester C. Peach Reseerch Engineer

Advisory Group on Electronic Parts

Room 103

Moore School Building

200 South 33rd Street

Philadelphia 4 , Pennsyl vania 
Ionosphere Research Laboratory

Pennsyluania State College

State College, Pennsylvanis

ATT, Profesaor A. H. Wamick, Director

Institute of Mathematical Sciences

25 Waverly Place

New York 3, Vev York

ATTN, Librarizn

Electronice Division

Rand Corporation

1700 Main Street

Santa Monica, Californía

ATTN: Dr. Robert Kalabo

National Bureau of Standaris

Washington, D. C.

ATTN, Dr. W. K. Saunders

Applied Mathematics and Statistics Lah. St. anford Uni versity

Stanford, alifornia

ATTN: Dr. Albert H. Bowlser

Department of Physics and Astrinomy

Michizan State College

East Lansing, Michigan

ATTN: Dr. A. Tejtner

Universitr of Tennessee

Knoxville, Tennessee

ATTN: Dr. Prel A. Ficken

Lebazon Ta?ley College

Annville, Pennsylvania

ATTN: Professor B.H. Bissinger

Gencral Atomic

P. 0 . Box 608

San Diego 12, California

Depertment of Physice

Anherst College

Amberst, Mass.

ATTNi Dr. Arnold Arons

California Institute of Technology

$1201 \mathrm{E}$. California Street

Pasadens, California

ATTN: Dr. A. Erdely1

Mathematjcs Department

Stanford linivergity

Stanford, Califomia

ATTN: Dr. Harold Levine

University of Minnesota

Minneapolis 1', Minnesots

ATTN, Professor Pzul C. Rosenhloom

Department of Mathematics

Stanford Univeraity

Stanford, Colifomia

ATTN: Professor Bernard Epstein

Applied Physics Laboratory

The John Hopkins Oni versity

R621 Georgia Avenue

Silver Spring. Maryland

ATTN: Dr. B. S. Gourary

(2)Exchange and Gift Division

The Library of Congress

Nashington $25, \mathrm{D}$. C.

Electrical Engineering Department Massachusetts Institutc of Technology Cambridge 39, Mass.

ATTN: Dr. I. J. Chu

Nuclear Develoment Associates, Inc. 5 New Street

White Plains, New York

ATTN: Libramy

California Institute of Technology

Electrical Engineering

Pasadena, Caltfornia

ATTN, Dr. Zohrab A. Kaprielian
Dr. Rodman Doll

311 W. Cross Street

Ppsilant1, Michizan

Californis Inst. of Technology

Pasadena, California

ATTN: Mr. Calvin Wilcox

(3) Mr. Robert Erockhurst

Woods Hole Oceanographic Institute Woods Hole, Mass.

National Bureau of Standards

Boulder, Colorado

ATTN: Dr. R. Gallet

Dr. Solomon L. Schwebel

3689 Louis Road

Palo Alto, Eelifornáa

University of Minnesot

The University of Library

Minneaoolis $\mathrm{L}_{4}$, Minnesota

ATTN, Exchange Division

Department of Mathematics

University of Califomia

Berkelev, Callfomia

ATTN: Profeszor Bernarl Friedman

Lincoln Laboratory

Massachusetts Institute of Technology

P. D. B०X73

Lexington 73, Massachuset to

ATTN: Dr. Shou Chin Wang, Room C-351

Melpar, Inc.

3000 Arlington Boulevsrd

Fallg Church, Virglnia

ATTN: Mr. K. S. Kelleher, Section Head

Ha. Air Force Cambridge Research Center

Laurence $G$. Hanscom Field

Bedford, Mass.

ATTV: Mr. Francis J. Zucker, CRRD

Hq. Afr Force Cambridge Researoh Center Laurence $G$. Yanscom Field

Bedford, Maas.

ATTN Dr. Ph1llp Newman, CRRK

Mr. N. C. Gerson

Trapelo Road

South Lincoln, Mass.

Dr. Richard B. Barrar

Systems Development Corp.

2400 Colorado Averne

Sant a Monica, Califomia

Columbia University Hudson Laboratories P.D. Box 239

145 Palisade Straet, Dobbs Ferry, N. Y

ATTN 1 Dr. N. W. Johnson

Institute of Fluid Dynamics

and Applied Mathematics

Uni versity of Maryland

College Park, Marvland

ATTN: Dr. Elliott Montroll

Department of Electrical Engl neertng

Washington University

Saint Louis 5, Mo

ATTN: Profesgor J. Van Bladel

Department of the Navy

Office of Naval Research Branch office

$1030 \mathrm{E}$. Green Street

Pasadena 1, California

Brandels "niversity

Waltham, Masa.

ATTN: Library

General Electr $r$ C Company

Mictowave Laboratory

Electronicg Divigion

Stanford Industrial Park

Palo Alto, California

ATTN: Library
Smyth Research Associates

3555 Aero Court

San Diego 3, California

ATTN: Dr. John 3. Smyth

Electrical Engineering

Californis Institute of Technolog.

Pagadena, California

ATTV: Dr deorges G. We1l

Naval Research Lahoratory

Washingt on 25, D. C.

ATTN: Henry J. Passerini, Code 5278A

Dr. Feorge Kear

5 Culver Court

Orinda, Californta

Brooklyn Polytechnic

85 Livingston Straet

Brooklyn, New York

ATTN: Dr. Nathan Marcuvitz

Department of Electrical Engineering Brcoklyn Polytechnic

R5 Livingston St reet

Brooklyn, New York

ATTN: Dr. Jerry Shmoys

Department of Mathematics

"nivergity of New Mexico

Albuquerque, New Mexico

ATTV: Dr. I. Kolodner

Mathematics Department

Polytechnic Institute of Brooklyn

Johnson and Jay Street

Brooklyn, New York

ATTN, Dr. Harry Hochetadt

Ballistics Regearch Laboratory

Abordeen Proving Grounds

Aberdeen, Maryland

ATTN: Dr. Pullen Reats

Dr. Lester Kraus

1.935 Whit.ehaven way

San Diego, Californis

University of Minsesota

Institute of Technology

Mi nneapoli6, Minnesota

At in: Dean Athelston Spilhaus

Ohio State University

Columbus, Ohio

Attn: Pror. C. T. Tai

Department of Electrical Eng.

Naval Research Laboratories

Washington 25, D. C.

Attn: W. S. Ament, Code 5271

Naval Research Liboratory

washington $25, \mathrm{D}$. C.

Attn: Dr. Leslie f. McCracken, $J_{r}$. Code 3933 A

Office of Naval Research

Deoartment of the Navy

Attn: Geophysics Branch, Code 416

Washington 25 , D. C.

Office of Chief Signal Officer

Signal plans and fperations Division

Attn: SIOOL-2. Room 2 ?

Com. Liaison Br., Radio Prop. Sect.

The Pentagon, Waghington 25, D. C.

Defence Research Member

Caradian Joint Staff

2001 Connecticut Street

Washington, D. C.

Central Radio Prop. Lab.

National Bureau of Standards

Attn: Technicel Reports Library

Boulder, Colorado

U. S. Weather Pureau

U. 5. Department of Commerce

Washingtion 25, D. C.

Attn: Dr. Horry wexler 
DL -6

Federal Communications Commiesion Washington $25, \mathrm{D}, \mathrm{C}$.

Attn: Mrs. Barbara C. Grimes, Librarian

Vpper Atmosphere Research Section

Central Radio Propagation Laboratory

National Bureau of Standards

Boulder, Colorado

Argone National Lahoratory

P. B. Box 299

Lemont, Illinols

Attn: Dr. Hoylande D. Youn?

Bell Telephone Labs.

Murray Hill, New Jersey

Attn: Dr. S. O. Rice, 3B - 203

Carnegle Institute of Washington Dept. of Terrestrial Magnetiam

52l] Broad Branch Road, N. W.

washington 15, D. C.

Attn: Lbrary

Georzis Tech Research Institute

$225 \mathrm{~N}$. Avenue, N. W.

Attn: Dr. James E. Boyd

Atlants, Georgis

University of Marvland

College Park, Maryland

Attn: Dr. A. Weingtein

Institute of Fluid Dynsmics

Masgachusetts Institute of Tech

Lincoln Laboratory

P. C. Box 73

Lexd neton 73, Massachuget ts

Att 0 Prof Padford,

Willow Pun Research Center

Iniversity of Michigan

Willow Run Airport

Ypgilant1, Michigan

Attn: Dr. C. L. Dolph

School of Engineering

New York University

Univergity Haights

New York, New York

Shall Fellowship Committee of

Shell companies Foundation, In

50 West 5 th Street

New York 20, N. Y

Attn: Mr.J. R. Janggan

Esso Reaearch and Engineering

P. ก. Box 51

Linden, New Jersey

Attn: Mr. C. L. Brown, Manage

Union Carbide and Carbon Corp.

30 E. L2nd Street

New York 17, New York

Attn: Mr. L. E. Erlandion

Convair

San Diego 12, Californis

Attn: Mr. Marvin Stern

Bell Telephons Labs., Inc.

1,63 weat Street

New York 13, N. Y.

Attn: Dr. Mervin J. Kelly

Englneering Library

University of Calfforni

405 Hilgard Avenue

Los Angeles 24, Californis
Convir, A Div, of General Dynamics Corp.

Fort Worth 1, Texas

Attn: F. W. Davia, Chi ef Engineer

Convalr. A Div, of General Dynamics Corp.

Pomona, Callfornia

Attn: C. I. Parrine

Ass't Div. Manager, Engin.

She11 Development Company

Exoloration and Production Ras. DLv.

3737 Bellaire Boulevard

Houston 25, Texas

Attri: Miss Aphrodite Mamculides

FCA Iaboratories

Princeton, New Jersey

Attn: Dr. Charles Folk

Stanford Research Institute

S. Pasadena, Caljfornia

Attn: Dr. J. Erandstatten

Wayne State University

Kresge-hooker Science L1brary

5250 Second Boulevard

Detroit. 2, Nichigan

ARRA
Major Vernon Lee Dawgon

RSDD-OML ( $\mathrm{MO})$

Redet one Arsenal

Huntsville, Alabams

Grumman Aircarft Engineer1ng Corp.

South Oyater Bay Road

Bethpace, Long Island, N. Y.

Attn: Dr. Charles Nack

AF office of Scifntific Resparch

washington $25, \mathrm{D}$. C.

Attn: Dr. Karl Kanlan

University of Californla

Radiation Laborat ory

F. O. BOX ROR

Livermore, California

Attn: Dr. Bernard A. Lipposinn

Depertment of Electrical Enginering Case Institute of Technolcgy

University Circle

$c 1$ eveland 6 , onio

Attn: Professor Altert E. Collin

Antenna Laboratory

Air Force Cambridge Research Center

Laurence G. Hanscom Field

Bedford, Massachusetts

Attn: Mr. Philip Blackstone

Mart J. Reran, CRPD

Force Cambridge Research Center ence G. Hanecom Field

ord, Nassachusetts

Richard Mack, CRRD

Force Cambidge Research Center

ence G. Hanscom Field

ord, Massachusetts

em Development Corporation

$\rightarrow$ Colorado Avenue

a Monira, California

: Library

Convair, A Division of General Lynamics worp.

Daingerield, Texas

Attn: J. E. Amold, Diviaion Manager

College or sribliteririt

Dept. of Electrical Engineering

Iniversity of Florida

Gaineeville, Florida

Convair, A Division of General Dynamics Corp. Attn: Dr. Sullivan

San Diego 12, Califormia

Attn: R. L. Bayleas, Chlef Englneer

Dr. V. M. Papadopoulos

Convirg Dept. of Engineering

San Diego 12, California

Attn: K. J. Bosgart, Chief Enginaer-WS107A

Brown Unt veraity
Providence, R. I. 


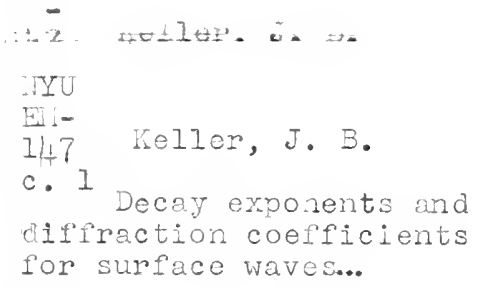

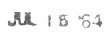

\section{N. Y. U. Institute of Mathematical Sciences}

25 Waverly Place New York 3, N. Y. 
